\title{
The effect of social benefit reform on educational inequality ${ }^{12}$
}

\author{
Nhat An Trinh ${ }^{*}$ \\ [For the latest version of this paper, see its published version in the Journal of Social Policy \\ https://doi.org/10.1017/S0047279422000848]
}

July 2021

\begin{abstract}
Cross-country research argues that the design of welfare states and social protection systems shapes the intergenerational transmission of inequality. Studies that examine this relationship within a country are however lacking from the literature. Using difference-in-differences estimation and data from the Socio-Economic Panel, I analyse whether children of unemployment assistance recipients have lower educational attainment after changes to eligibility criteria, benefit levels and conditionality were introduced in Germany in 2005. I find that differences in the probability to attend the academic secondary school track between children of unemployment assistance recipients and children living in families, where no benefits are claimed, increased by 13 percentage points. In part, this was driven by the introduction of means-testing that changed the composition of unemployment assistance recipients towards the more disadvantaged. However, a further worsening in the financial conditions of these already disadvantaged families following reductions in benefit criteria appear as the main driver of the observed effect. By contrast, changes in parental subjective wellbeing due to increased benefit conditionality and stigma do not appear to play a significant mediating role.
\end{abstract}

\footnotetext{
${ }^{1}$ I am grateful to Erzsébet Bukodi, Per Engzell, Caspar Kaiser, Brian Nolan, Aaron Reeves, Mary-Alice Dolye as well as attendees of the RC28 Spring Meeting 2021 for their helpful comments and suggestions. I thank survey respondents for their participation in the SOEP as well as the German Institute for Economic Research (DIW) for making available the data on which this research draws.

${ }^{2}$ A previous version was circulated under the title 'Hartz IV and educational attainment: Investigating the causal effect of social benefit reform on intergenerational inequalities in Germany'.

* nhatan.trinh@spi.ox.ac.uk, Barnett House, 32 Wellington Square, Oxford OX1 2ER, United Kingdom.
} 
To date, research struggles to pinpoint the degree to which the design of welfare states and social protection systems compensate or reinforce intergenerational inequalities. Most studies adopt comparative, cross-national designs to investigate the association between public institutions and the transmission of disadvantage across generations (Beller and Hout 2006; Esping-Andersen 2014; Bukodi et al. 2017; Lindemann and Gangl 2020). Unfortunately, however, these do not allow for a robust estimation of causal relationships given issues of unobserved heterogeneity. The small number of studies that are able to exploit exogenous variation are limited to assessing the impact of educational systems (Betthäuser 2017; Pischke and von Wachter 2008; Sturgis and Buscha 2015). Whether and how characteristics of social protection systems are causally linked to levels of intergenerational inequality is therefore unclear.

During the early 2000s, Germany's labour market and social protection system underwent radical reorganisation that led to an unprecedented shift from conservative Bismarckian principles of social insurance towards greater activation and employment flexibilization. Although more than a decade has passed, the so-called 'Hartz reforms' remain contested and are a recurring subject of public and political debate (Süddeutsche Zeitung 2019; Der Spiegel 2020). While Hartz I-III (implemented in 2003 and 2004) comprised the introduction of new and the reform of existing active labour market policies, Hartz IV (implemented in 2005) modified unemployment and social benefit regulations. Its main feature was to merge unemployment assistance for the long-term unemployed and social assistance for those in need into one benefit scheme called 'Arbeitslosengeld II'. As a result, individuals who are unemployed for more than a year lost their insurance-based claim to earnings-related benefits. Unemployment assistance is now only provided if household incomes fall below subsistence level and has become highly conditional on active job search and participation in active labour market programmes.

The German Hartz IV reform thus offers a unique opportunity to study the impact of the social protection system on the intergenerational transmission of inequality based on a natural experiment. By removing earnings-related benefits for the long-term unemployed and increasing benefit conditionality for those in need, it seems likely that Hartz IV not only affected the generation of current workers but also the outcomes and opportunities of their offspring. Still, we lack evidence on such intergenerational effects of the reform. These effects might be particularly detrimental and arguably unjust, as children who experience parental unemployment form already a disadvantaged group. Previous studies show that children with unemployed parents have lower levels of educational attainment compared to children whose parents work (Brand 2015; Coelli 2011; Kalil and Wightman 2011; Lohmann and Groh-Samberg 2017; Lindemann and Gangl 2019). Lower educational attainment, in turn, translates into poorer labour market outcomes and life chances more broadly. It is therefore vital to know whether Hartz IV reinforced the transmission of disadvantage across generations, thereby widening intergenerational inequalities.

By taking up this task, this study makes two contributions to the literature. Firstly, it expands the existing micro- and macro-economic evidence on the reform's effect on unemployment levels and duration (Krause and Uhlig 2012; Launov and Wälde 2013; Hochmuth et al. 2021), job matching efficiency (Hertweck and Sigrist 2012), and wages (Bradley and Kügler 2019) by analyses that focus on inequality-generating processes that occur within families rather than the labour market. Investigating the outcomes of children of benefit recipients allows to identify long-lasting social 
consequences, which might have neither been anticipated nor intended when the reform was first devised.

Secondly, the study sheds further light on the role of public institutions in fostering social mobility and equality of opportunity. Past research suggests that social policies can work as an institutional moderator of the association between social origin and social destination. Employing hierarchical modelling techniques to analyse data from 21 countries, Lindemann and Gangl (2020) show that generous unemployment benefits mitigate the negative effect of parental unemployment on children's transition into tertiary education. However, by using a quasi-experimental approach focussing on a single country, it is possible to pinpoint even more precisely the causal effect of characteristics of the unemployment and social protection system on educational inequalities.

The objective of this study is to evaluate the effect of the 2005 Hartz IV reform on families that receive unemployment assistance and their children's educational attainment. I therefore focus on a particularly vulnerable group, namely households that experience long-term unemployment and qualify for benefits. Given that in Germany the transition from primary to secondary school is highly predictive of future training and labour market opportunities, secondary school track attainment is chosen as children's outcome of interest. The next section outlines in greater detail Germany's unemployment and social benefit system before and after the implementation of Hartz IV. I then elaborate on why the reform likely led to lower educational attainment for children of unemployment assistance recipients. The subsequent section describes the analytical strategy followed by the presentation of the empirical findings. A discussion of their implications for future research and policymaking is provided in the final section.

\section{The German unemployment and social benefit system before and after 2005}

In the comparative welfare state literature, Germany is considered a key representative of the conservative welfare state regime (Esping-Andersen 1990). Organised based on the principle of social insurance, its welfare institutions centre around the worker and are underpinned by strong tripartite partnerships between employees, employers, and the state.

Until the early 2000s, Germany's protection of the unemployed consisted of two pillars (Hassel and Schiller 2010). Both aimed at safeguarding the individual from experiencing a drop in living standards due to unemployment. The first pillar was 'Arbeitslosengeld', i.e. unemployment benefits from social insurance. These were generally paid for 12 months to individuals with social insurance contributions of at least 12 months during a qualifying period of 2 years before becoming unemployed. Depending on overall contributions, older individuals could even receive benefits for up to 36 months. Benefit levels were equivalent to 67 and 60 percent of previous earnings for individuals with and without children, respectively. The second pillar was 'Arbeitslosenhilfe', i.e. tax-funded unemployment assistance. Transfers from unemployment assistance were in principle unlimited and paid to individuals, whose claim to unemployment benefits expired. They were therefore also conditional on social insurance contributions. Replacement rates amounted to 57 and 53 percent for individuals with and without children, respectively. Payments could only cease if recipients repeatedly refused to accept work that was comparable to their previous employment or current benefit levels (Bäcker and Koch 2004). 
Implemented on January 1, 2005, the Hartz IV reform combined the second pillar of unemployment protection with flat-rate basic income support for those in need. Before the reform, 'Sozialhilfe', i.e. tax-funded social assistance, provided all individuals in need who were not covered by unemployment insurance with a minimum social security net. Its main purpose was to reduce poverty and to guarantee a legally defined socio-cultural subsistence level within households. Thus, individuals received social assistance only upon passing a means test, and refusal to take up work was strictly sanctioned with benefit cuts. There was hence a clear difference in benefit generosity and conditionality for individuals whose entitlement to social benefits was based on previous employment and social contribution records vis-à-vis financial hardship.

After the reform, this distinction eroded. Since 2005 entitlement to earnings-related benefits ends with the expiration of unemployment benefits, which older workers can now receive for a shorter maximum duration of 18 months (Bäcker 2017). Individuals who remain unemployed for a longer period are only eligible for means-tested, flat-rate basic income support. Figure 1 illustrates how benefit schemes and levels change by unemployment duration before and after the reform.

[Figure 1]

The main objective behind this dramatic policy shift was to reduce long-term unemployment and welfare dependance (Jacobi and Kluve 2006). During the 1990s, the proportion of long-term unemployed among all unemployed had increased to over 50 percent (OECD 2020). For this purpose, Hartz IV also redefined the category of people in need and divided them into two groups based on their ability to work (Goebel and Richter 2007). Individuals who can work for at least 3 hours per day need to apply to the newly created unemployment assistance scheme 'Arbeitslosengeld II' (henceforth ALGII). ${ }^{1}$ Individuals who cannot work for at least 3 hours per day, and who do not share a household with someone eligible for unemployment assistance, continue to receive social assistance. While benefit levels are similar, the main difference between the two schemes is that unemployment assistance is now highly conditional on active job search and participation in activation measures as well as related labour market programmes. Accordingly, harsh sanctions for non-compliance were introduced for recipients of unemployment assistance. ${ }^{2}$ By contrast, sanctions for recipients of social assistance were omitted after the reform as they are no longer subject to labour market integration. Table 1 gives an overview of the main characteristics of the unemployment and social benefit schemes that were in place before and after the introduction of Hartz IV.

[Table 1]

\section{$3 \quad$ Hartz IV and children's educational attainment}

Over the past decades, levels of education have greatly increased in Germany due to vast educational expansion (Pollak and Müller 2020). Nevertheless, family background is still a strong predictor of children's academic achievements (Shavit and Blossfeld 1993; Blossfeld 2018) and intergenerational social mobility low by international comparison (Bukodi, Paskov, and Nolan 2020). Hartz IV might have contributed to these persisting inequalities by reducing the educational 
attainment of children of unemployment assistance recipients against concurrent efforts towards greater educational equalisation.

Two mechanisms are conceivable through which Hartz IV reduced the educational attainment of children living in families that receive unemployment assistance. First, Hartz IV changed the composition of unemployment assistance recipients towards the more disadvantaged by altering eligibility criteria. Second, Hartz IV adversely affected parental resources and wellbeing by altering benefit levels and conditionality.

As described in the previous section, the introduction of strict means-testing implies that since 2005 a smaller group of the long-term unemployed is eligible for unemployment assistance compared to before. Only those receive the benefit, whose incomes fall below subsistence level. Families that can maintain a higher level of income, e.g. because one parent is still employed and earns sufficiently well, are excluded. Families receiving unemployment assistance after the reform are therefore likely to form a more socio-economically disadvantaged group than families receiving unemployment assistance before the reform. Specifically, the proportion of low educated, working class or single parents could be higher. Consequently, a decline in the educational attainment of children of unemployment assistance recipients is observed.

However, there is evidence that Hartz IV also had a direct impact on family resources and wellbeing. Goebel and Richter (2007) show that more than 50 percent of individuals who switched from 'Arbeitslosenhilfe' to ALGII experienced a loss in income following changes in benefit levels. In the first year of the reform two in three households receiving unemployment assistance had incomes below 60 percent of median income, and the poverty gap ${ }^{3}$ was with 18.5 percent almost twice as high as the poverty gap for households receiving unemployment assistance one year before. These reductions in the financial resources of unemployment assistance recipients could lead to lower educational attainment in the second generation by affecting their performance in school as well as choices regarding educational careers (Boudon 1974). On the one hand, parents have fewer means to advance their children's learning through buying additional material such as books and computers. They are also less likely to afford private tutoring lessons or summer schools (Duncan and Brooks-Gunn 1997; Kaushal, Magnuson, and Waldfogel 2011). On the other hand, their ability to finance longer periods of education and training is reduced. They are hence less likely to opt for the academic educational trajectory that takes significantly more time to complete than the vocational qualification route. The former requires at least three additional years of school even before starting university.

Moreover, the reform turned the receipt of unemployment assistance into a more taxing experience, aggravating the well-documented negative effects of unemployment on individuals' subjective wellbeing (Clark 2003; Oesch and Lipps 2013). Deter (2020) reports that Hartz IV led to lower levels of life satisfaction among the long-term unemployed. As explained earlier, recipients of unemployment assistance are now strictly monitored by public employment agencies in their efforts to find work and are required to participate in active labour market programmes. Additionally, policymakers used language of blame and contempt, creating a dooming narrative around social benefit recipients, when introducing the Hartz reforms to the public (Fohrbeck, Hirseland, and Lobato 2014). ${ }^{4}$ Over and above the psychological costs of lower incomes (Kahnemann and Deaton 2010), parents receiving unemployment assistance after the reform are therefore exposed to greater stress as well as stigmatisation compared to parents receiving 
unemployment assistance before the reform. This in turn can lead to poorer academic performance among their children. Parental emotional wellbeing creates a stable home environment for children's flourishing development (Kalil 2013) and ensures parents' capacity to offer effective help with school-related activities such as doing homework (Murray et al. 2006). Thus, given the detrimental effects of lower benefit levels and stricter benefit conditionality on family resources and wellbeing, children of unemployment assistance recipients could have lower educational attainment after the introduction of Hartz IV.

In some part, I hence expect negative selection to account for lower educational attainment among children of unemployment assistance recipients. Nevertheless, this process is to be considered an integral part of the reform. As the pool of eligible families is restricted to those on low incomes, the reform's potential negative consequences on family resources and wellbeing are exclusively channelled towards the most disadvantaged, worsening their conditions even further. If this is the case, it follows that Hartz IV increased intergenerational inequalities by reinforcing the intergenerational transmission of disadvantage at the very bottom of society.

\section{$4 \quad$ Analytical strategy}

Data

All analyses are based on the Socio-Economic Panel (SOEP), which is Germany's largest representative, longitudinal survey. Every year around 30,000 individuals in ca. 11,000 households are interviewed on different aspects of their life including education, labour market participation, economic conditions, and family composition. The main analytical sample consists of children who transitioned from primary to secondary school between 2001-2010 and is split symmetrically into a pre- and post-reform group. For 2,464 children this transition is directly observed. Using information on average transition age by birth year and state of residence, I further impute year of transition for another 327 children, who were already in secondary school by the time of the survey. ${ }^{5}$ Information on these children's education is then combined with data on parental benefit receipt from the year preceding their transition from primary to secondary school. Parental information for the pre- and post-reform group refer to the period 2000-2004 and 2005-2009, respectively. Children are linked to their parents using identifiers provided in the annual childspecific files. Thus, rather than using identifiers on their biological parents, I match children to those parents with whom they live and interact on a daily basis.

\section{Key variables}

The transition from primary to secondary school around age 10 constitutes a critical moment in the educational trajectories of German children. Due to rigid tracking practices, type of secondary school has long-lasting consequences on academic achievements and labour market careers (Neugebauer et al. 2013). Traditionally, three types of secondary schools exist in the German educational system. The lower ('Hauptschule') and intermediate ('Realschule') secondary schools provide vocational education, whereas the higher secondary school ('Gymnasium') focusses more on academic education. However, over the past decades, this three-track system increasingly moved 
towards a two-tiered system that was accompanied by the creation of comprehensive schools offering different school leaving degrees under the same roof (Becker, Neumann, and Dumont 2017). I therefore measure children's educational attainment using a binary variable that takes the value 1 if they enter the 'Gymnasium', i.e. academic track, and 0 if they attend any of the other two secondary school tracks. Despite recent changes to Germany's secondary school structure, the 'Gymnasium' has kept its status and prestige, and exists in all federal states as the only school that exclusively offers the university entrance exam 'Abitur'. It therefore provides direct access to university training and is also increasingly required for more prestigious post-secondary vocational programmes.

Parental benefit receipt is measured using information from both the annual individual as well as household questionnaires. I distinguish between four categories: (1) no benefits, (2) unemployment benefits, (3) unemployment assistance, and (4) social assistance. Following Table 1, 'Arbeitslosengeld' is coded as unemployment benefits, 'Arbeitslosenhilfe' is coded as unemployment assistance, and 'Sozialhilfe' is coded as social assistance. Since ALGII is not only accessible to the unemployed but also to workers on low incomes, I use information on past benefit receipt to assign recipients of ALGII the relevant benefit category. Recall that 'Arbeitslosenhilfe' was only paid to those whose claim to unemployment benefits expired. Parents who reported unemployment benefits immediately before receiving ALGII are therefore comparable to recipients of 'Arbeitslosenhilfe'. Accordingly, ALGII is coded as unemployment assistance if it was directly preceded by 'Arbeitslosengeld' in the previous four years ${ }^{6}$, or by 'Arbeitslosenhilfe'. Parents who did not receive unemployment benefits before obtaining ALGII in the stated period are identified as recipients of social assistance.

Parents might receive benefits from multiple schemes during a year. Also, they can receive different benefits at the same time because transfers from unemployment insurance are paid as an individuallevel benefit, whereas basic income support is targeted at the entire household. I therefore measure parental benefit receipt on the household level. Parents are considered receiving social assistance if it was claimed for at least three months regardless of any other benefit received. Parents are considered receiving unemployment assistance if unemployment assistance was received for at least three months and social assistance was not reported for more than two months. Similarly, parents are considered receiving unemployment benefits if these were received for at least three months, and none of the other benefits were reported for more than two months. Children are considered living in no-benefit households if social assistance, unemployment assistance, or unemployment benefits were not received for more than two months. Periods of benefit receipt of less than three months appear rather transitional and are therefore unlikely to bear significant consequences for children's educational attainment. The four benefit categories are hence mutually exclusive, comparable across the pre- and post-reform period, and comprise all children who made the transition from primary to secondary school during the stated observation window.

\section{Modelling}

To identify the effect of the Hartz IV reform on the educational attainment of children of unemployment assistance recipients, I adopt a quasi-experimental research design based on difference-in-differences (DiD) estimation (Angrist and Pischke 2008). Although the reform was implemented simultaneously across Germany and thus affected the entire population at the same 
time, it seems plausible that families that did not receive any of the benefits discussed were least affected by the reform. Children living in such families are therefore taken as reference group against which pre- and post-reform differences in academic track attendance for children with parents receiving unemployment assistance are compared. For completeness and to account for potential spill-over effects, I also compare pre- and post-reform differences in academic track attendance between children living in families, where parents do not receive benefits and where parents receive unemployment benefits or social assistance.

For unbiased identification, the DiD-estimator rests on the so-called 'parallel trends assumption'. This assumption states that pre-treatment trends in the outcome of interest are similar for the two groups that are compared against one another. Accordingly, the probability to attend the academic track for children of benefit recipients and those who do not receive benefits should follow a similar trend before the introduction of Hartz IV. I scrutinise the validity of this assumption alongside a series of placebo identification tests in the 'robustness section' below. Overall, the results stand robust against these tests.

Using ordinary-least-squares regression ${ }^{7}$, I estimate linear probability models of the following form:

$$
\begin{aligned}
\pi_{i t}=\alpha & +\beta_{b} \text { BEN }_{i b t-1}+\sigma R E F O R M_{t-1}+\lambda_{b}\left(\text { BEN }_{i b t-1} \times \text { REFORM }_{t-1}\right) \\
& +\varphi X_{i t-1}+\phi\left(X_{i t-1} \times \text { REFORM }_{t-1}\right)+\tau_{t-1}+\varepsilon_{i t}
\end{aligned}
$$

where $\pi_{i t}$ indicates whether child $i$ entered the academic track after primary school in year $t$. $B E N_{i b t-1}$ denotes a set of dummies for parental benefit receipt $b$ in year $t-1$, i.e. one year before the child's transition. $R E F O R M_{t-1}$ is a dummy that indicates whether parental benefit receipt is observed before or after the reform. It takes the value 0 if parental benefit receipt is observed in year $t-1<2005$, and 1 otherwise. $B E N_{i b t-1} \times R E F O R M_{t-1}$ identifies whether the association between children's academic track attendance in $t$ and parental benefit receipt $b$ in $t-1$ changed after the reform relative to children whose parents did not receive any benefits. $X_{i t-1}$ and $X_{i t-1} \times R E F O R M_{t-1}$ denote a vector of covariates and their interaction with the reform dummy. The interaction is included to model potential changes in the association between these covariates and academic track attendance across the two periods. $\tau_{t-1}$ is a year fixed-effect ${ }^{8}$ and $\varepsilon_{i t}$ stands for the error term.

The baseline model includes controls for the child's sex, age at the transition from primary to secondary school as well as the state where the transition took place 9 . I then add a term for net equivalised household income minus transfers from unemployment and social assistance in $t-1$. Controlling for pre-benefit household income allows to examine how far observed changes in academic track attendance for children of unemployment assistance recipients are driven by the introduction of strict means-testing, and thus selection. To take account of further differences between families receiving unemployment assistance before and after the reform, controls for a range of socio-demographic characteristics are added to the model. These are the number of children younger than 15 in the household, whether living with a single parent, mean parental age (squared), parental migration background, parental education, and parental social class in $t-1$. In cases where mother's and father's education or class position differ, the higher is taken. 
Next, I include terms for total net equivalised household income as well as parental life satisfaction in $t-1$. I do so to test for the mediating effects of changes in family resources and wellbeing due to reduced benefit levels and increased benefit conditionality. Parental life satisfaction is measured on a scale from 0 to 10, where higher values indicate higher life satisfaction. In cases where mother's and father's life satisfaction differ, the lower value is taken. Unfortunately, the SOEP does not provide more detailed information on parents' stress level and parent-child interactions for the observation period in question. Table 2 displays the distributions of all variables included in the analysis, separately for the pre- and post-reform samples.

[Table 2]

\section{$5 \quad$ Empirical findings}

Table 3 presents OLS estimates for attending the academic track for children, who transitioned to secondary school between 2001 and 2010 in Germany. Column 1 shows the main effects of parental benefit receipt, accounting for the reform dummy and set of baseline controls. Living in families that receive unemployment or social benefits is associated with substantively lower chances to transition to the academic track. On average, children whose parents receive unemployment benefits are 16 percentage points less likely to transition to the academic track than children whose parents do not receive benefits. For children of unemployment and social assistance recipients the gap amounts to 26 and 31 percentage points, respectively.

[Table 3]

These large differences are not surprising. Whether parents receive benefits or not depends on their position in the labour market and financial situation. Both are known to be highly predictive of children's educational attainment (Becker and Nietfeld 1999; Lohmann and Groh-Samberg 2017). Moreover, the observed gradient in the probability to transition to the academic track corresponds to differences in the characteristics and target groups of the three benefit schemes (see Table 1). Given that recipients of unemployment benefits enjoy more generous replacement rates and are exposed to shorter periods of unemployment than recipients of unemployment assistance, educational disadvantages are plausibly smaller for children of the former than the latter. Conversely, families that claim social assistance generally struggle the most with financial hardship and poverty. It is thus reasonable that the greatest disadvantage is observed for children of social assistance recipients.

In column 2, the interaction with the reform dummy is included. The main effects for parental benefit receipt now denote differences in academic track attendance during the pre-reform period, and the interactions with the reform dummy identify changes in these differences after the introduction of Hartz IV. Their sums hence indicate post-reform inequalities in the probability to attend the academic track. In line with expectations, I observe a sizable and statistically significant drop in the probability to attend the academic track for children of unemployment assistance recipients. For children who made the transition before 2006, parental unemployment assistance receipt is associated with a 22 percentage points lower chance to attend the academic track relative to having parents that do not receive benefits. After the reform, this gap increases to 35 percentage 
points. Differences in the probability to attend the academic secondary school track between children of unemployment assistance recipients and children living in families, where no benefits are claimed, thus increased by 13 percentage points.

By contrast, the interaction terms for the other two benefit types are much smaller. The coefficient for parental unemployment benefit receipt is negative and the coefficient for parental social assistance receipt is positive. There is hence indication that inequalities for children of unemployment benefit recipients also increased, while inequalities for children of social assistance recipients somewhat declined. However, both coefficients are not statistically significant.

In column 3, a term for net equivalised household income before transfers from unemployment and social assistance is added. I thereby control for potential differences between unemployment assistance recipients before and after the reform that arise from the introduction of means-testing. The interaction between the reform dummy and parental unemployment assistance decreases by around one fifth and is now only marginally statistically significant. Nevertheless, the estimated post-reform gap in academic track attendance for children of unemployment assistance recipients still amounts to 17 percentage points. As can be seen in Figure 2, it is also statistically significant at 95 percent, whereas the estimated pre-reform gap of 7 percentage points no longer is. Accounting for additional socio-demographic characteristics in column 4 does not change the overall picture further.

[Figure 2]

Hartz IV thus shifted the composition of unemployment assistance recipients towards the more disadvantaged, which in turn accounts for roughly 20 percent of the estimated reform effect. This change in the composition of unemployment assistance recipients is an important observation. It means that it is the most disadvantaged families, who are affected by the reform's potential adverse consequences on family resources and wellbeing. If so, Hartz IV would perpetuate intergenerational inequalities at the very bottom of society.

Indeed, adding a term for total net equivalised household income in column 5 reduces the coefficient essentially to zero (-0.016) and turns it statistically insignificant. In other words, I no longer observe meaningful pre- and post-reform differences in the gap to enter the academic track between children of unemployment assistance recipients and those living in no-benefit families (see also Figure 1). Controlling for parental life satisfaction in column 6 brings the coefficient for the interaction between the reform dummy and parental unemployment assistance receipt even closer to zero (-0.014). However, given the already small size of the coefficient and no changes in the coefficients for pre-benefit and total household income between columns 5 and 6 (full results shown in appendix Table A1), it seems unlikely that parental life satisfaction plays a substantive mediating role. A worsening in family's financial resources following reductions in benefit levels therefore appears as the main driver of the observed decline in the probability to attend the academic track for children of unemployment assistance recipients. 
To gauge the robustness of the results, a series of additional analyses is conducted. First, I fit the main effects model (cf. Table 1, column 1) on the pre-reform sample only and interact the year fixed-effects with parental benefit receipt to test the validity of the parallel trends assumption that is key to the DiD approach. The results are shown in appendix Table A3. None of the interactions with parental unemployment assistance receipt is statistically significant. The same applies if I specify a linear year trend, providing supportive evidence that trends in academic track attendance did not differ between children of unemployment assistance recipients and those with parents not receiving benefits before the reform.

Next, I pretend that the reform was already implemented in 2001 and assign transition cohorts to the pre- and post-reform group accordingly. Prior to Hartz IV, Germany's unemployment and social benefit system was modified for the last time in 1997. Children who transitioned to secondary school between 1998-2001 are hence assigned to the pre-reform group, whereas children who made the transition between 2002-2005 now form the post-reform group. As mentioned in the introduction, Hartz IV was part of an entire reform package ('Agenda 2010'). Re-running the analyses with this placebo thus inspects whether the observed rise in educational inequalities can be ascribed to any of the other three reforms that were introduced before.

Analogously, I check whether the observed changes in academic track attendance among children of unemployment assistance recipients were driven by some other event that occurred after 2005 (e.g. financial crisis). For this second placebo analysis, I pretend that the reform was implemented in 2010. Children who transitioned to secondary school between 2006-2010 are hence assigned to the pre-reform group and children who made the transition between 2011-2013 are assigned to the post-reform group. ${ }^{10}$

Appendix Table A3 shows no statistically significant reform interaction for either placebo test. I therefore do not find indication for a violation of the parallel trends assumption, nor evidence that the observed decline in the educational attainment of children whose parents receive unemployment assistance was driven by any event other than Hartz IV.

\section{$7 \quad$ Discussion}

This study examined how far radical and still contested changes to Germany's unemployment and social benefit system in 2005 affected intergenerational inequalities. Exploiting exogenous variation induced by the Hartz IV reform, which altered eligibility criteria, benefit levels and conditionality for unemployment assistance, it overcame methodological limitations of prior work that relied on the comparison of different countries.

I find that children of unemployment assistance recipients experienced a 13 percentage-point decrease in their probability to enter the academic secondary school track after Hartz IV was implemented. To some extent, this effect was brought about by alterations of eligibility criteria and the introduction of means-testing, which shifted the composition of unemployment assistance recipients towards the more socio-economically disadvantaged. The main driver, however, appears 
to be a further worsening in the financial conditions of these already disadvantaged parents after Hartz IV replaced earnings-related benefits with flat-rate basic income support for the long-term unemployed (Goebel and Richter 2007). Although past studies document a negative effect of the reform on the subjective well-being of the long-term unemployed (Deter 2020), changes in parental life satisfaction do not seem to contribute to the observed decline in children's chances to transition to the academic track.

These results are in line with the existing, albeit small, literature on the capacity of generous social policies to alleviate the adverse effects of parental unemployment on children's education (Lindemann and Gangl 2020). They show that even in Germany, where education is generally free of charge, benefit generosity is an important instrument by which the welfare state can effectively protect workers as well as their children against the detrimental consequences of unemployment. More attention therefore needs to be directed towards the role played by social protection systems and the welfare state in moderating the intergenerational relationship.

For researchers, this means to extend the present analyses to different contexts and settings. By focussing on a single country, this study significantly complements comparative, cross-country research on the impact of social protection systems on intergenerational inequalities. Nevertheless, it is important to know whether similar effects will be observed when different welfare institutions and schemes, which differ in purpose and design, are put under scrutiny in different countries and time periods. Future research may also benefit from exploring additional mechanisms through which social protection systems could shape the intergenerational transmission of disadvantage. The inclusion of more comprehensive measures of emotional wellbeing, which go beyond life satisfaction, as well as information on mother's and father's parenting styles and behaviour could help in determining the significance of parental psychological resources (or the lack thereof) more precisely. Looking at child outcomes other than education might be another useful avenue for extension.

For policymakers, the findings highlight that decisions about the design of welfare systems and benefit schemes have far-reaching consequences. Replacing 'Arbeitslosenhilfe' with ALGII undermined the protective function of the conservative welfare state, leading to the reinforcement of disadvantage at the very bottom of society in Germany. Some may consider this problematic. Whether overall reductions in long-term unemployment and welfare dependence can justify the observed increase in educational inequalities for such a vulnerable group is therefore subject to moral and political deliberation. The present analyses act as an important reminder that changes to public institutions that directly affect people's livelihoods require careful consideration. Balancing trade-offs may go beyond a single generation.

\footnotetext{
${ }^{1}$ It is important to note that ALGII is therefore not only accessible to individuals without employment but can also be claimed by those on low incomes as an in-work benefit (Eichhorst and Marx 2011).

${ }^{2}$ Sanctions are divided into three steps. Refusal to accept a job offer could be penalised with 30 percent benefit cuts if occurred for the first time, and 60 percent benefit cuts if occurred for the second time. Additional violations within the same year could lead to loss of the entire benefit. Moreover, recipients could be sanctioned with 10 percent benefit cuts if they miss appointments at the public employment agency. In November 2019, the Federal Constitutional Court ruled that sanctions of more than 30 percent are unconstitutional (Der Tagesspiegel 2019).

3 The poverty gap measures the extent to which individuals' income fall short from the poverty line. In this case, it measures the percentage by which individuals' income are below 60 percent of median income.

${ }^{4}$ In colloquial language, the term "hartzen" even developed, referring to people being lazy, free-riding, and passively dependent on social welfare.
} 
${ }^{5}$ In the pre- and post-reform group, the proportion of children, for whom year of transition from primary to secondary school is imputed, is 13.32 percent and 9.56 percent, respectively.

${ }^{6}$ For the majority of children, this period covers the entire time spent in primary education. Except for some federal states such as Berlin and Brandenburg, where the transition occurs after six years in primary school, the transition generally occurs after grade four. It thus seems plausible that changes from unemployment benefits to unemployment assistance have the greatest impact on secondary school transitions during this period. In addition, parents who receive ALGII for more than four years, regardless of whether this was preceded by 'Arbeitslosengeld' or not, likely constitute a rather specific group, and are more likely to be comparable with recipients of social assistance than unemployment assistance.

${ }^{7}$ For ease of interpretation, and in order to compare coefficients across models (cf. Mood 2010; Breen, Karlson, and Holm 2013), OLS is preferred over logistic regression. Results do not substantively change when using the latter (see appendix Table A2).

8 To achieve identification of the reform dummy, the sums of coefficients referring to the pre-reform period (20002004) and of the coefficients referring to the post-reform period (2005-2009) are constrained to zero.

${ }^{9}$ For children, for whom year of transition is imputed, state of residence for the year that comes closest to the transition is used.

10 Appendix Figure A1 gives an overview of the different transition cohorts that are used as pre- and post-reform groups in the main and auxiliary analyses. 


\section{References}

Angrist, Joshua, and Jörn-Steffen Pischke. 2008. Mostly Harmless Econometrics. Princeton University Press.

Bäcker, Gerhard. 2017. Chronologie Gesetzlicher Neuregelungen: Arbeitsförderung/SGB III \& Arbeitsrecht 1998-2016. Universität Duisburg-Essen.

Bäcker, Gerhard, and Angelika Koch. 2004. Absicherung Bei Langzeitarbeitslosigkeit: Zentrale Unterschiede Zwischen Zukünftigem Arbeitslosengeld II, Bisheriger Arbeitslosenbilfe Und Bisheriger Sozialhilfe. Universität Duisburg-Essen.

Becker, Michael, Marko Neumann, and Hanna Dumont. 2017. 'Recent Developments in School Tracking Practices in Germany: An Overview and Outlook on Future Trends'. ORBIS SCHOLAE 10 (3): 9-25.

Becker, Rolf, and Markus Nietfeld. 1999. 'Arbeitslosigkeit und Bildungschancen von Kindern im Transformationsprozeß. Eine Empirische Studie über die Auswirkungen sozio-ökonomischer Deprivation auf intergenerationale Bildungsvererbung'. Kölner Zeitschrift Für Soziologie Und Sozialpsychologie 51 (1): 55-79.

Beller, Emily, and Michael Hout. 2006. 'Welfare States and Social Mobility: How Educational and Social Policy May Affect Cross-National Differences in the Association between Occupational Origins and Destinations'. Research in Social Stratification and Mobility 24 (4): 353-65.

Betthäuser, Bastian. 2017. 'Fostering Equality of Opportunity? Compulsory Schooling Reform and Social Mobility in Germany'. European Sociological Review 33 (5): 633-44.

Blossfeld, Pia Nicoletta. 2018. Changes in Inequality of Educational Opportunity. Wiesbaden: Springer Fachmedien Wiesbaden.

Boudon, Raymond. 1974. Education, Opportunity, and Social Inequality: Changing Prospects in Western Society. New York: Wiley.

Bradley, Jake, and Alice Kügler. 2019. 'Labor Market Reforms: An Evaluation of the Hartz Policies in Germany'. European Economic Review 113 (April): 108-35.

Brand, Jennie E. 2015. 'The Far-Reaching Impact of Job Loss and Unemployment'. Annual Review of Sociology 41 (1): 359-75.

Breen, Richard, Kristian Bernt Karlson, and Anders Holm. 2013. 'Total, Direct, and Indirect Effects in Logit and Probit Models'. Sociological Methods \& Research 42 (2): 164-91. 
Bukodi, Erzsébet, Ferdinand Eibl, Sandra Buchholz, Sonia Marzadro, Alessandra Minello, Susanne Wahler, Hans-Peter Blossfeld, Robert Erikson, and Antonio Schizzerotto. 2017. 'Linking the Macro to the Micro : A Multidimensional Approach to Educational Inequalities in Four European Countries'. European Societies, 1-39.

Bukodi, Erzsébet, Marii Paskov, and Brian Nolan. 2020. 'Intergenerational Class Mobility in Europe: A New Account'. Social Forces.

Clark, Andrew. 2003. 'Unemployment as a Social Norm: Psychological Evidence from Panel Data'. Journal of Labor Economics 21 (2): 323-51.

Coelli, Michael B. 2011. 'Parental Job Loss and the Education Enrollment of Youth'. Labour Economics 18 (1): 25-35.

Der Spiegel. 2020. 'Grüne Wollen Hartz IV Grundlegend Verändern', 2020. https://www.spiegel.de/politik/deutschland/gruene-wollen-hartz-iv-grundlegend-veraenderna-41c1af5e-6f19-47ec-8dc5-9ec51aef78c8.

Der Tagesspiegel. 2019. 'Sanktionen Sind Teilweise Verfassungswidrig', 2019. https://www.tagesspiegel.de/politik/hartz-iv-urteil-sanktionen-sind-teilweise-

verfassungswidrig/25183746.html.

Deter, Max. 2020. 'Hartz and Minds: Happiness Effects of Reforming an Employment Agency'. Journal of Happiness Studies, July.

Duncan, Greg, and Jeanne Brooks-Gunn, eds. 1997. Consequences of Growing up Poor. New York: Russell Sage Foundation.

Eichhorst, Werner, and Paul Marx. 2011. 'Reforming German Labour Market Institutions: A Dual Path to Flexibility'. Journal of European Social Policy 21 (1): 73-87.

Esping-Andersen, Gøsta. 1990. The Three Worlds of Welfare Capitalism. Cambridge, UK: Polity Press. . 2014. 'Welfare Regimes and Social Stratification'. Journal of European Social Policy 25 (1): 124 34.

Fohrbeck, Anna, Andreas Hirseland, and Philipp Ramos Lobato. 2014. 'How Benefits Recipients Perceive Themselves through the Lens of the Mass Media - Some Observations from Germany'. Sociological Research Online 19 (4): 74-81.

Goebel, Jan, and Maria Richter. 2007. 'Nach der Einführung von Arbeitslosengeld II: Deutlich mehr Verlierer als Gewinner unter den Hilfeempfängern'. DIW Wochenbericht 74 (50): 753-62. 
Hassel, Anke, and Christof Schiller. 2010. 'Die Politische Dynamik von Arbeitsmarktreformen in Deutschland Am Beispiel Der Hartz IV-Reform'. Abschlussbericht.

Hertweck, Matthias, and Oliver Sigrist. 2012. 'The Aggregate Effects of the Hartz Reforms in Germany'. University of Konstanz. Working Paper 38.

Hochmuth, Brigitte, Britta Kohlbrecher, Christian Merkl, and Hermann Gartner. 2021. 'Hartz IV and the Decline of German Unemployment: A Macroeconomic Evaluation'. Journal of Economic Dynamics and Control 127 (June): 104114.

Jacobi, Lena, and Jochen Kluve. 2006. 'Before and After the Hartz Reforms: The Performance of Active Labour Market Policy in Germany'. IZA Discussion Paper No. 2100.

Kahneman, Daniel and Angus Deaton. 2010. 'High income improves evaluation of life but not emotional well-being'. Proceedings of the National Academy of Sciences of the United States of America, 107, 16489-16493.

Kalil, Ariel. 2013. 'Effects of the Great Recession on Child Development'. Edited by Sheldon Danziger. The ANNALS of the American Academy of Political and Social Science 650 (1): 232-50.

Kalil, Ariel, and Patrick Wightman. 2011. 'Parental Job Loss and Children's Educational Attainment in Black and White Middle-Class Families'. Social Science Quarterly 92 (1): 57-78.

Kaushal, Neeraj, Katherine Magnuson, and Jane Waldfogel. 2011. 'How Is Family Income Related to Investments in Children's Learning?' In Whither Opportunity? Rising Inequality and the Uncertain Life Chances of Low-Income Children, edited by Richard Murnane and GregJ. Duncan, pp. 187-206. New York: Russell Sage Foundation.

Krause, Michael U., and Harald Uhlig. 2012. 'Transitions in the German Labor Market: Structure and Crisis'. Journal of Monetary Economics 59 (1): 64-79.

Launov, Andrey, and Klaus Wälde. 2013. 'Estimating Incentive and Welfare Effects of Nonstationary Unemployment Benefits'. International Economic Review 54 (4): 1159-98.

Lindemann, Kristina, and Markus Gangl. 2019. 'The Intergenerational Effects of Unemployment: How Parental Unemployment Affects Educational Transitions in Germany'. Research in Social Stratification and Mobility 62 (August): 100410.

2020. 'Parental Unemployment and the Transition into Tertiary Education: Can Institutions Moderate the Adverse Effects?’ Social Forces 99 (2): 616-47.

Lohmann, Henning, and Olaf Groh-Samberg. 2017. 'Elterliche Arbeitslosigkeitsdynamiken und Bildungsverläufe vom Ende der Grundschulzeit bis zum jungen Erwachsenenalter'. KZfSS Kölner Zeitschrift für Soziologie und Sozialpsychologie 69 (4): 623-50. 
Mood, C. 2010. 'Logistic Regression: Why We Cannot Do What We Think We Can Do, and What We Can Do About It'. European Sociological Review 26 (1): 67-82.

Murray, Lynne, Matt Woolgar, Carla Martins, Anna Christaki, Alison Hipwell, and Peter Cooper. 2006. 'Conversations around Homework: Links to Parental Mental Health, Family Characteristics and Child Psychological Functioning’. British Journal of Developmental Psychology 24 (1): 125-49.

Neugebauer, Martin, David Reimer, Steffen Schindler, and Volker Stocké. 2013. 'Inequality in Transitions to Secondary School and Tertiary Education in Germany'. In Determined to Succeed?, edited by Michelle Jackson, pp. 56-88. Stanford University Press.

Oesch, Daniel, and Oliver Lipps. 2013. 'Does Unemployment Hurt Less If There Is More of It Around? A Panel Analysis of Life Satisfaction in Germany and Switzerland'. European Sociological Review 29 (5): 955-67.

Pischke, Jörn-Steffen, and Till von Wachter. 2008. 'Zero Returns to Compulsory Schooling in Germany: Evidence and Interpretation'. The Review of Economics and Statistics 90 (3): 592-98.

Pollak, Reinhard, and Walter Müller. 2020. 'Education as an Equalizing Force: How Declining Educational Inequality and Educational Expansion Have Contributed to More Social Fluidity in Germany'. In Education and Intergenerational Social Mobility in Europe and the United States, edited by Richard Breen and Walter Müller, pp. 122-49. Stanford, California: Stanford University Press.

Shavit, Yossi, and Hans-Peter Blossfeld, eds. 1993. Persistent Inequality: Changing Educational Attainment in Thirteen Countries. Social Inequality Series. Boulder, Colo: Westview Press.

Sturgis, Patrick, and Franz Buscha. 2015. 'Increasing Inter-Generational Social Mobility: Is Educational Expansion the Answer?: Increasing Inter-Generational Social Mobility'. The British Journal of Sociology 66 (3): 512-33.

Süddeutsche Zeitung. 2019. 'Der Abschied von Hartz IV Ist Ein Nötiger Neuanfang', 2019. https://www.sueddeutsche.de/wirtschaft/pro-und-contra-zur-sozialen-wende-der-spd-derabschied-von-hartz-iv-ist-ein-noetiger-neuanfang-1.4325088. 
Figure 1. Benefit schemes and levels by unemployment duration, before and after reform

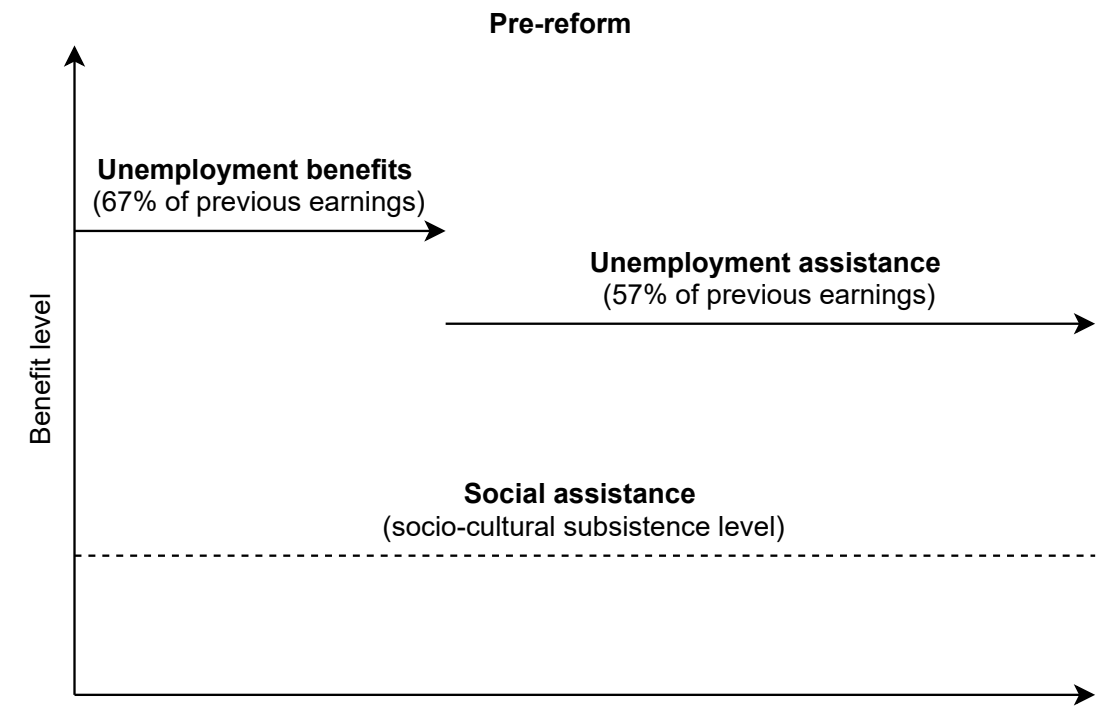

Unemployment duration

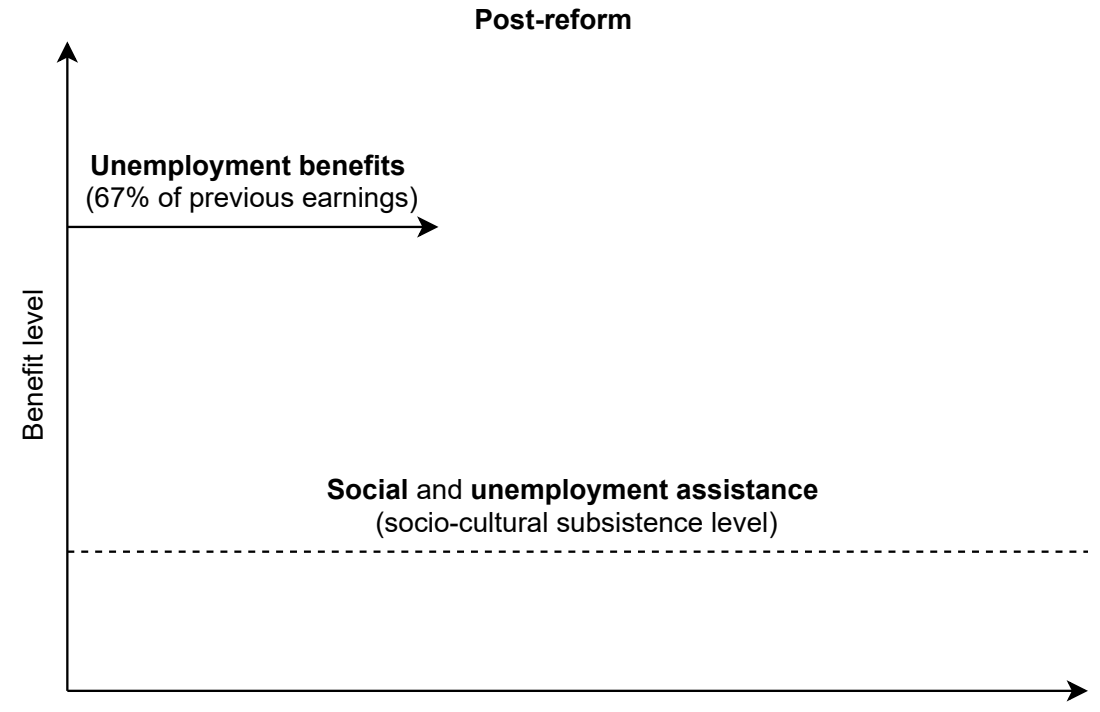

Unemployment duration 
Table 1. Unemployment and social benefit schemes before and after the Hartz IV reform

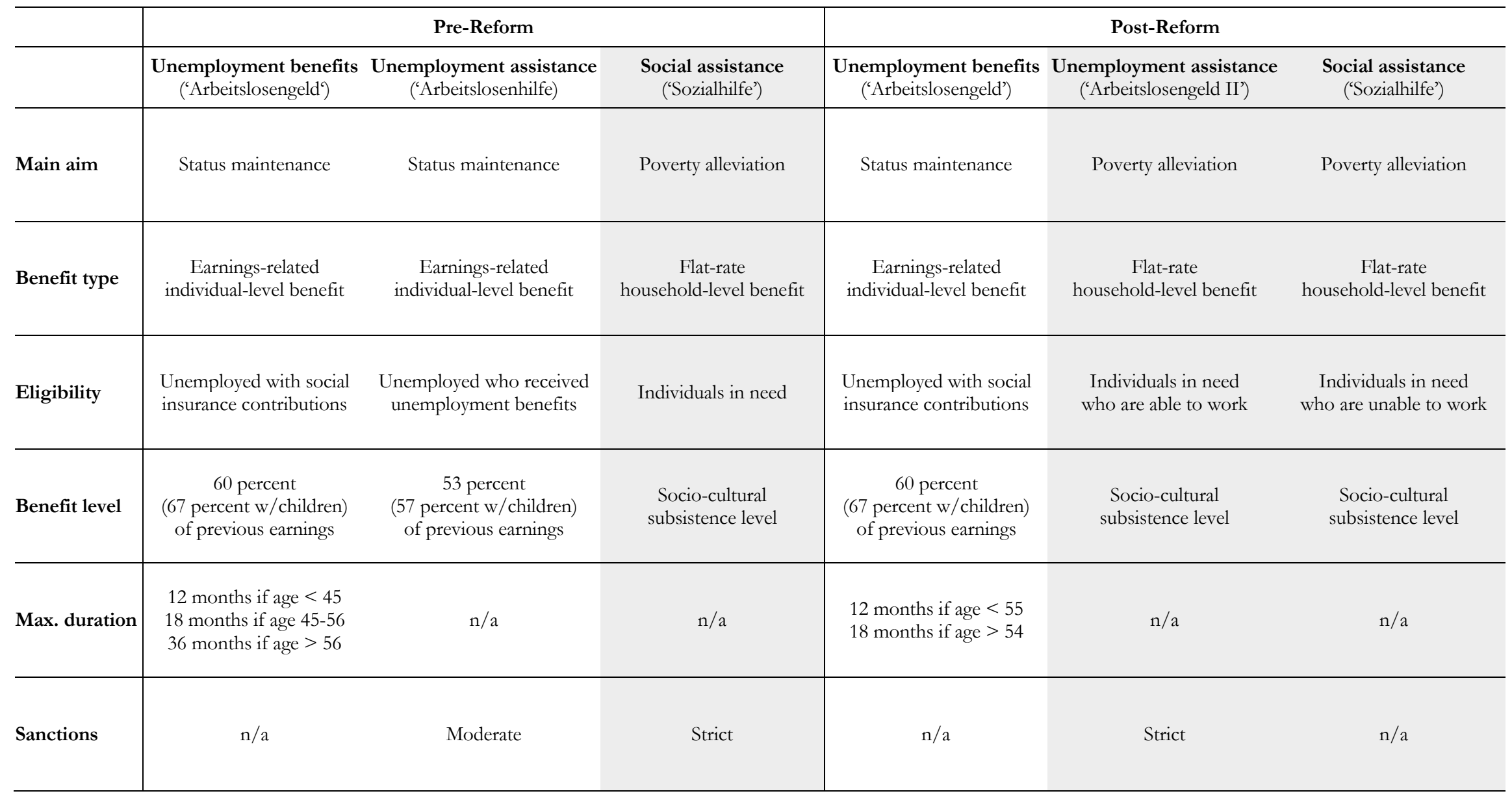

Note: Own illustration based on Bäcker and Koch (2004), Boucarde (2007), Hassel and Schiller (2010). White-shaded area indicates unemployment insurance scheme and grey-shaded area indicates basic income support scheme. 
Table 2. Descriptives

\begin{tabular}{|c|c|c|c|c|c|c|c|c|c|}
\hline & \multicolumn{2}{|c|}{$\begin{array}{l}\text { Pre-reform } \\
(2000-2004)\end{array}$} & \multicolumn{2}{|c|}{$\begin{array}{c}\text { Post-reform } \\
(2005-2009)\end{array}$} & & \multicolumn{2}{|c|}{$\begin{array}{l}\text { Pre-reform } \\
(2000-2004)\end{array}$} & \multicolumn{2}{|c|}{$\begin{array}{l}\text { Post-reform } \\
(2005-2009)\end{array}$} \\
\hline & $\% /$ Mean & $\overline{\mathrm{SD}}$ & $\% /$ Mean & $\overline{\mathrm{SD}}$ & & $\% /$ Mean & $\overline{\mathrm{SD}}$ & $\% /$ Mean & SD \\
\hline Child characteristics & & & & & Parental characteristics & & & & \\
\hline Academic track attendance & 33.40 & & 38.59 & & Benefit receipt & & & & \\
\hline Year started secondary school & & & & & No benefit receipt & 86.43 & & 87.33 & \\
\hline 2001 & 24.83 & & & & Unemployment benefits & 4.88 & & 3.27 & \\
\hline 2002 & 19.26 & & & & Unemployment assistance & 5.25 & & 2.60 & \\
\hline 2003 & 20.26 & & & & Social assistance & 3.44 & & 6.80 & \\
\hline 2004 & 17.76 & & & & & & & & \\
\hline 2005 & 17.89 & & & & & & & & \\
\hline 2006 & & & 23.99 & & Education (ISCED97) & & & & \\
\hline 2007 & & & 22.82 & & Pre-primary & 1.13 & & 0.34 & \\
\hline 2008 & & & 20.64 & & Primary & 6.00 & & 5.96 & \\
\hline 2009 & & & 16.53 & & Lower secondary & 43.28 & & 39.68 & \\
\hline \multirow{2}{*}{2010} & & & 16.02 & & Upper secondary & 7.38 & & 9.14 & \\
\hline & & & & & Post-secondary tertiary & 13.13 & & 15.52 & \\
\hline Federal state of secondary school & & & & & Tertiary & 29.08 & & 29.36 & \\
\hline Schleswig-Holstein & 3.00 & & 2.35 & & & & & & \\
\hline Hamburg & 1.25 & & 1.59 & & & & & & \\
\hline Lower Saxony & 10.44 & & 9.98 & & Social class (ESeC) & & & & \\
\hline Bremen & 0.44 & & 0.50 & & Salariat & 41.84 & & 47.48 & \\
\hline North Rhine-Westphalia & 20.76 & & 21.81 & & Intermediate class & 24.89 & & 25.59 & \\
\hline Hesse & 7.44 & & 8.39 & & Working class & 30.83 & & 24.50 & \\
\hline Rhineland-Palatinate & 6.94 & & 6.63 & & Never worked & 2.44 & & 2.43 & \\
\hline Baden-Württemberg & 14.57 & & 14.26 & & & & & & \\
\hline Bavaria & 17.01 & & 16.86 & & & & & & \\
\hline Saarland & 1.38 & & 1.09 & & Age & 39.06 & 5.02 & 40.06 & 4.89 \\
\hline Berlin & 2.81 & & 1.68 & & Single parent & 8.82 & & 12.16 & \\
\hline Brandenburg & 3.69 & & 2.43 & & Migration background & 25.02 & & 24.24 & \\
\hline Mecklenburg-Vorpommern & 1.50 & & 1.51 & & Life satisfaction & 6.66 & 1.69 & 6.62 & 1.72 \\
\hline Saxony & 3.75 & & 5.70 & & & & & & \\
\hline Saxony-Anhalt & 2.63 & & 2.10 & & & & & & \\
\hline \multirow[t]{2}{*}{ Thuringia } & 2.38 & & 3.10 & & Household characteristics & & & & \\
\hline & & & & & Number of children age $0-14$ & 1.90 & 0.86 & 1.87 & 0.87 \\
\hline Age at transition to secondary school & 10.61 & 0.77 & 10.46 & 0.70 & Pre-benefit income $(2000 €)$ & 16,996 & 8,963 & 17,372 & 10,705 \\
\hline Female & 48.59 & & 48.41 & & Total income $(2000 €)$ & 17,243 & 8,703 & 17,833 & 10,282 \\
\hline$\overline{\mathbf{N}}$ & 1,599 & & 1,192 & & $\mathbf{N}$ & 1,599 & & 1,192 & \\
\hline
\end{tabular}


Table 3. Academic track attendance by parental benefit receipt, before and after reform (OLS)

\begin{tabular}{|c|c|c|c|c|c|c|}
\hline & $\begin{array}{c}\text { (1) } \\
\text { Main effects }\end{array}$ & $\begin{array}{c}(2) \\
\text { Baseline }\end{array}$ & $\begin{array}{c}\text { (3) } \\
+ \text { Pre-benefit } \\
\text { HH income }\end{array}$ & $\begin{array}{c}\text { (4) } \\
+ \text { Socio- } \\
\text { demographics }\end{array}$ & $\begin{array}{c}(5) \\
+ \text { Total } \\
\text { HH income } \\
\end{array}$ & $\begin{array}{c}(6) \\
+ \text { Parental life } \\
\text { satisfaction }\end{array}$ \\
\hline \multicolumn{7}{|l|}{$\begin{array}{l}\text { Parental benefit receipt } \\
\text { (ref.: No benefits) }\end{array}$} \\
\hline Unemployment benefits & $\begin{array}{r}-0.164^{* * *} \\
(0.040)\end{array}$ & $\begin{array}{r}-0.131^{* *} \\
(0.052)\end{array}$ & $\begin{array}{l}-0.061 \\
(0.049)\end{array}$ & $\begin{array}{l}-0.006 \\
(0.045)\end{array}$ & $\begin{array}{l}-0.006 \\
(0.045)\end{array}$ & $\begin{array}{l}-0.000 \\
(0.046)\end{array}$ \\
\hline Unemployment assistance & $\begin{array}{r}-0.255^{* * *} \\
(0.035)\end{array}$ & $\begin{array}{r}-0.223^{* * *} \\
(0.043)\end{array}$ & $\begin{array}{r}-0.067^{+} \\
(0.046)\end{array}$ & $\begin{array}{l}-0.053 \\
(0.046)\end{array}$ & $\begin{array}{l}-0.056 \\
(0.062)\end{array}$ & $\begin{array}{l}-0.044 \\
(0.062)\end{array}$ \\
\hline Social assistance & $\begin{array}{r}-0.306^{* * * *} \\
(0.029)\end{array}$ & $\begin{array}{r}-0.331^{* * *} \\
(0.034)\end{array}$ & $\begin{array}{r}-0.140^{* * *} \\
(0.038)\end{array}$ & $\begin{array}{r}-0.127^{* * *} \\
(0.047)\end{array}$ & $\begin{array}{r}-0.130^{* *} \\
(0.063)\end{array}$ & $\begin{array}{r}-0.131^{* *} \\
(0.063)\end{array}$ \\
\hline Reform & $\begin{array}{c}0.041^{* *} \\
(0.018)\end{array}$ & $\begin{array}{c}0.312^{* *} \\
(0.134)\end{array}$ & $\begin{array}{c}0.326^{* *} \\
(0.129)\end{array}$ & $\begin{array}{l}0.662 \\
(0.726)\end{array}$ & $\begin{array}{l}0.592 \\
(0.730)\end{array}$ & $\begin{array}{l}0.561 \\
(0.730)\end{array}$ \\
\hline $\begin{array}{l}\text { Unemployment benefits } \\
\times \text { Reform }\end{array}$ & & $\begin{array}{l}-0.094 \\
(0.079)\end{array}$ & $\begin{array}{l}-0.094 \\
(0.076)\end{array}$ & $\begin{array}{l}-0.100 \\
(0.073)\end{array}$ & $\begin{array}{l}-0.079 \\
(0.073)\end{array}$ & $\begin{array}{l}-0.073 \\
(0.073)\end{array}$ \\
\hline $\begin{array}{l}\text { Unemployment assistance } \\
\times \text { Reform }\end{array}$ & & $\begin{array}{c}-0.129^{*} \\
(0.066)\end{array}$ & $\begin{array}{r}-0.105^{+} \\
(0.071)\end{array}$ & $\begin{array}{r}-0.104^{+} \\
(0.070)\end{array}$ & $\begin{array}{l}-0.016 \\
(0.091)\end{array}$ & $\begin{array}{l}-0.014 \\
(0.090)\end{array}$ \\
\hline $\begin{array}{l}\text { Social assistance } \\
\times \text { Reform }\end{array}$ & & $\begin{array}{l}0.052 \\
(0.056)\end{array}$ & $\begin{array}{l}0.040 \\
(0.063)\end{array}$ & $\begin{array}{l}0.050 \\
(0.068)\end{array}$ & $\begin{array}{c}0.144^{+} \\
(0.096)\end{array}$ & $\begin{array}{c}0.155^{+} \\
(0.096)\end{array}$ \\
\hline Year- and state-fixed effects & Yes & Yes & Yes & Yes & Yes & Yes \\
\hline $\mathrm{N}$ & 2,791 & 2,791 & 2,791 & 2,791 & 2,791 & 2,791 \\
\hline
\end{tabular}

$+0.15,{ }^{*} \mathrm{p}<0.10,{ }^{* *} \mathrm{p}<0.05,{ }^{* * *} \mathrm{p}<0.01$. Pre-treatment period 2000-2004, post-treatment period: 2005-2009. Robust standard errors in parentheses. All models control for child's age at transition from primary to secondary school and sex. Socio-demographic controls include number of children age 0-14 in the household, living with single parent, parental age(-squared), parental migration background, parental education, and parental social class one year before transition. Full results shown in appendix Table A1. SOEP v.34. 
Figure 2. Differences in academic track attendance for children of unemployment assistance recipients relative to children whose parents do not receive benefits, before and after reform

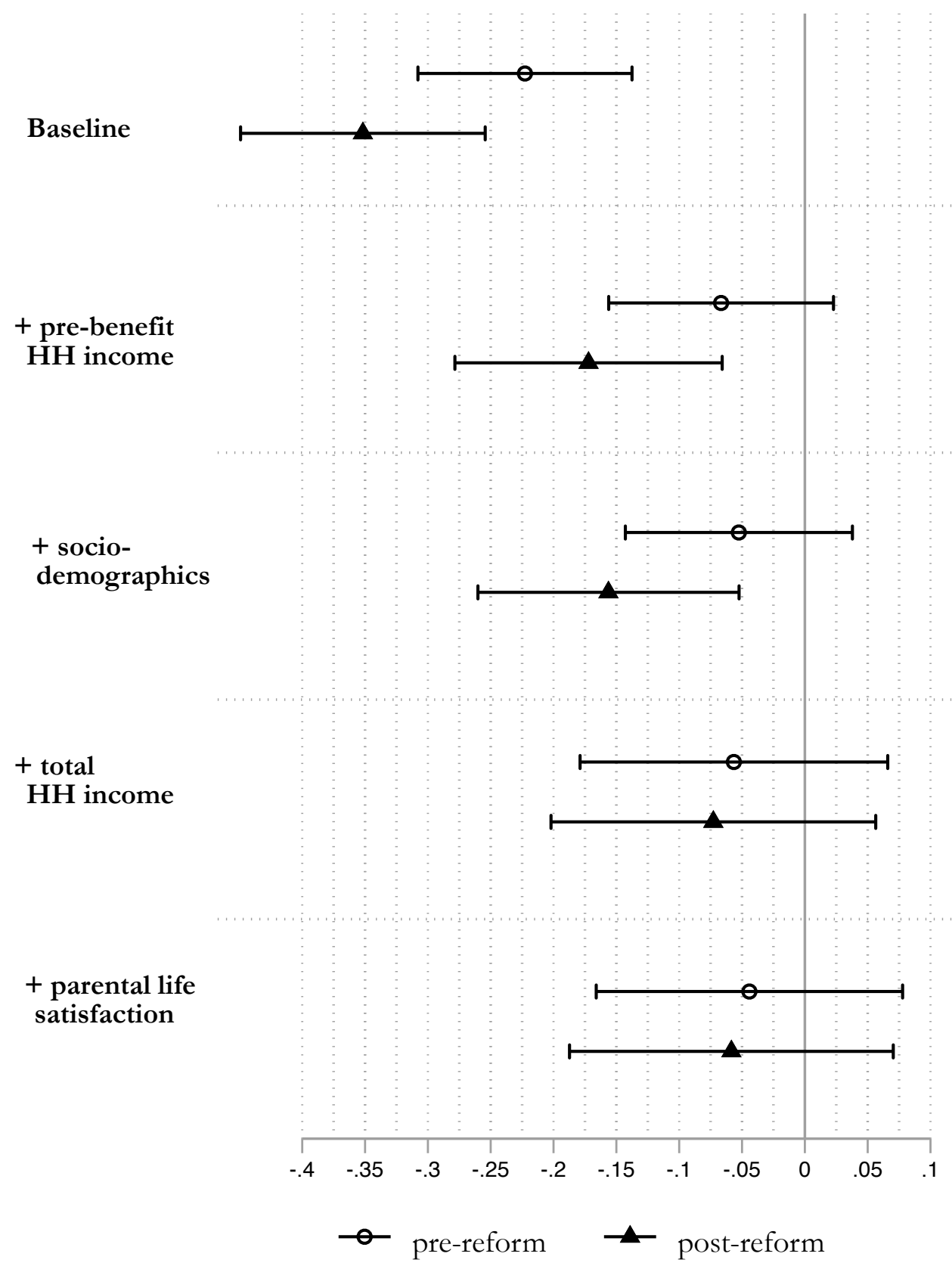

Note: Based on Table 3, columns (2)-(6). 95 percent confidence intervals shown. 
APPENDIX 
Table A1. Academic track attendance by parental benefit receipt, before and after reform (OLS, full)

\begin{tabular}{|c|c|c|c|c|c|c|}
\hline & $\begin{array}{c}(1) \\
\text { Main effects }\end{array}$ & $\begin{array}{c}(2) \\
\text { Baseline }\end{array}$ & $\begin{array}{c}(3) \\
+ \text { Pre-benefit } \\
\text { HH income }\end{array}$ & $\begin{array}{c}\text { (4) } \\
+ \text { Socio- } \\
\text { demographics }\end{array}$ & $\begin{array}{c}\text { (5) } \\
+ \text { Total } \\
\text { HH income }\end{array}$ & $\begin{array}{c}(6) \\
+ \text { Parental life } \\
\text { satisfaction }\end{array}$ \\
\hline \multicolumn{7}{|l|}{$\begin{array}{l}\text { Parental benefit receipt } \\
\text { (ref.: No benefits) }\end{array}$} \\
\hline Unemployment benefits & $\begin{array}{r}-0.164^{* * *} \\
(0.040)\end{array}$ & $\begin{array}{r}-0.131^{* *} \\
(0.052)\end{array}$ & $\begin{array}{l}-0.061 \\
(0.049)\end{array}$ & $\begin{array}{l}-0.006 \\
(0.045)\end{array}$ & $\begin{array}{l}-0.006 \\
(0.045)\end{array}$ & $\begin{array}{l}-0.000 \\
(0.046)\end{array}$ \\
\hline Unemployment assistance & $\begin{array}{r}-0.255^{* * *} \\
(0.035)\end{array}$ & $\begin{array}{r}-0.223^{* * *} \\
(0.043)\end{array}$ & $\begin{array}{r}-0.067^{+} \\
(0.046)\end{array}$ & $\begin{array}{l}-0.053 \\
(0.046)\end{array}$ & $\begin{array}{l}-0.056 \\
(0.062)\end{array}$ & $\begin{array}{l}-0.044 \\
(0.062)\end{array}$ \\
\hline Social assistance & $\begin{array}{r}-0.306^{* * *} \\
(0.029)\end{array}$ & $\begin{array}{r}-0.331^{* * *} \\
(0.034)\end{array}$ & $\begin{array}{r}-0.140^{* * *} \\
(0.038)\end{array}$ & $\begin{array}{r}-0.127^{* * *} \\
(0.047)\end{array}$ & $\begin{array}{r}-0.130^{* *} \\
(0.063)\end{array}$ & $\begin{array}{r}-0.131^{* *} \\
(0.063)\end{array}$ \\
\hline Reform & $\begin{array}{l}0.041^{* *} \\
(0.018)\end{array}$ & $\begin{array}{l}0.312^{* *} \\
(0.134)\end{array}$ & $\begin{array}{l}0.326^{* *} \\
(0.129)\end{array}$ & $\begin{array}{l}0.662 \\
(0.726)\end{array}$ & $\begin{array}{l}0.592 \\
(0.730)\end{array}$ & $\begin{array}{l}0.561 \\
(0.730)\end{array}$ \\
\hline Unemployment benefits & & -0.094 & -0.094 & -0.100 & -0.079 & -0.073 \\
\hline$\times$ Reform & & $(0.079)$ & $(0.076)$ & $(0.073)$ & $(0.073)$ & $(0.073)$ \\
\hline Unemployment assistance & & $-0.129^{*}$ & $-0.105^{+}$ & $-0.104^{+}$ & -0.016 & -0.014 \\
\hline$\times$ Reform & & $(0.066)$ & $(0.071)$ & $(0.070)$ & $(0.091)$ & $(0.090)$ \\
\hline Social assistance & & 0.052 & 0.040 & 0.050 & $0.144^{+}$ & $0.155^{+}$ \\
\hline$\times$ Reform & & $(0.056)$ & $(0.063)$ & $(0.068)$ & $(0.096)$ & $(0.096)$ \\
\hline \multicolumn{7}{|l|}{ Age at transition (ref.: 9) } \\
\hline 10 & $\begin{array}{r}0.145^{* * *} \\
(0.037)\end{array}$ & $\begin{array}{r}0.161^{* * *} \\
(0.047)\end{array}$ & $\begin{array}{r}0.134^{* * *} \\
(0.045)\end{array}$ & $\begin{array}{r}0.130^{* * *} \\
(0.046)\end{array}$ & $\begin{array}{r}0.130^{* * *} \\
(0.046)\end{array}$ & $\begin{array}{r}0.132^{* * *} \\
(0.046)\end{array}$ \\
\hline 11 & $\begin{array}{r}0.100^{* * * *} \\
(0.037)\end{array}$ & $\begin{array}{r}0.160^{* * *} \\
(0.047)\end{array}$ & $\begin{array}{r}0.156^{* * *} \\
(0.045)\end{array}$ & $\begin{array}{c}0.158^{* * *} \\
(0.046)\end{array}$ & $\begin{array}{r}0.158^{* * * *} \\
(0.046)\end{array}$ & $\begin{array}{c}0.158^{* * * *} \\
(0.046)\end{array}$ \\
\hline 12 & $\begin{array}{l}0.015 \\
(0.047)\end{array}$ & $\begin{array}{c}0.091^{+} \\
(0.059)\end{array}$ & $\begin{array}{l}0.100^{*} \\
(0.057)\end{array}$ & $\begin{array}{l}0.110^{*} \\
(0.057)\end{array}$ & $\begin{array}{c}0.111^{*} \\
(0.057)\end{array}$ & $\begin{array}{c}0.111^{*} \\
(0.058)\end{array}$ \\
\hline 13 & $\begin{array}{l}0.055 \\
(0.127)\end{array}$ & $\begin{array}{l}0.041 \\
(0.128)\end{array}$ & $\begin{array}{l}0.085 \\
(0.125)\end{array}$ & $\begin{array}{l}0.137 \\
(0.129)\end{array}$ & $\begin{array}{l}0.137 \\
(0.129)\end{array}$ & $\begin{array}{l}0.136 \\
(0.129)\end{array}$ \\
\hline 14 & $\begin{array}{r}-0.174^{* *} \\
(0.073)\end{array}$ & $\begin{array}{c}-0.234^{*} \\
(0.120)\end{array}$ & $\begin{array}{c}-0.156 \\
(0.116)\end{array}$ & $\begin{array}{c}-0.156 \\
(0.135)\end{array}$ & $\begin{array}{c}-0.156 \\
(0.135)\end{array}$ & $\begin{array}{c}-0.158 \\
(0.136)\end{array}$ \\
\hline $10 \times$ Reform & & $\begin{array}{c}-0.040 \\
(0.075)\end{array}$ & $\begin{array}{c}-0.024 \\
(0.074)\end{array}$ & $\begin{array}{c}-0.046 \\
(0.070)\end{array}$ & $\begin{array}{c}-0.042 \\
(0.070)\end{array}$ & $\begin{array}{c}-0.047 \\
(0.071)\end{array}$ \\
\hline $11 \times$ Reform & & $\begin{array}{c}-0.144^{*} \\
(0.075)\end{array}$ & $\begin{array}{c}-0.131^{*} \\
(0.073)\end{array}$ & $\begin{array}{c}-0.132^{*} \\
(0.070)\end{array}$ & $\begin{array}{c}-0.128^{*} \\
(0.071)\end{array}$ & $\begin{array}{c}-0.131^{*} \\
(0.071)\end{array}$ \\
\hline $12 \times$ Reform & & $\begin{array}{r}-0.194^{* *} \\
(0.095)\end{array}$ & $\begin{array}{r}-0.182^{\text {*** }} \\
(0.092)\end{array}$ & $\begin{array}{r}-0.184^{* *} \\
(0.090)\end{array}$ & $\begin{array}{c}-0.178^{*} \\
(0.091)\end{array}$ & $\begin{array}{r}-0.181^{* *} \\
(0.091)\end{array}$ \\
\hline $13 \times$ Reform & & $\begin{array}{r}0.840^{* * *} \\
(0.177)\end{array}$ & $\begin{array}{r}0.774^{\text {*** }} \\
(0.172)\end{array}$ & $\begin{array}{r}0.773^{* * *} \\
(0.176)\end{array}$ & $\begin{array}{c}0.711^{\text {**** }} \\
(0.177)\end{array}$ & $\begin{array}{c}0.713^{* * *} \\
(0.178)\end{array}$ \\
\hline $14 \times$ Reform & & $\begin{array}{l}0.042 \\
(0.167)\end{array}$ & $\begin{array}{l}0.005 \\
(0.161)\end{array}$ & $\begin{array}{l}0.029 \\
(0.184)\end{array}$ & $\begin{array}{l}0.044 \\
(0.184)\end{array}$ & $\begin{array}{c}-0.008 \\
(0.187)\end{array}$ \\
\hline Female & $\begin{array}{l}0.008 \\
(0.018)\end{array}$ & $\begin{array}{l}0.007 \\
(0.023)\end{array}$ & $\begin{array}{l}0.008 \\
(0.023)\end{array}$ & $\begin{array}{l}0.026 \\
(0.022)\end{array}$ & $\begin{array}{l}0.026 \\
(0.022)\end{array}$ & $\begin{array}{l}0.026 \\
(0.022)\end{array}$ \\
\hline Female $\times$ Reform & & $\begin{array}{l}-0.005 \\
(0.036)\end{array}$ & $\begin{array}{l}0.007 \\
(0.035)\end{array}$ & $\begin{array}{l}-0.010 \\
(0.034)\end{array}$ & $\begin{array}{l}-0.009 \\
(0.034)\end{array}$ & $\begin{array}{l}-0.007 \\
(0.034)\end{array}$ \\
\hline Pre-benefit income & & & $\begin{array}{r}0.015^{* * *} \\
(0.001)\end{array}$ & $\begin{array}{r}0.006^{* * *} \\
(0.002)\end{array}$ & $\begin{array}{l}0.004 \\
(0.016)\end{array}$ & $\begin{array}{l}0.004 \\
(0.016)\end{array}$ \\
\hline Pre-benefit income & & & -0.002 & 0.001 & 0.028 & 0.028 \\
\hline$\times$ Reform & & & $(0.002)$ & $(0.002)$ & $(0.020)$ & $(0.020)$ \\
\hline HH members age $0-14$ & & & & $\begin{array}{l}0.018 \\
(0.013)\end{array}$ & $\begin{array}{l}0.018 \\
(0.013)\end{array}$ & $\begin{array}{l}0.016 \\
(0.013)\end{array}$ \\
\hline HH members age 0-14 & & & & -0.001 & -0.000 & 0.000 \\
\hline$\times$ Reform & & & & $(0.019)$ & $(0.019)$ & $(0.019)$ \\
\hline Parental age & & & & $\begin{array}{l}0.025 \\
(0.021)\end{array}$ & $\begin{array}{l}0.025 \\
(0.021)\end{array}$ & $\begin{array}{l}0.025 \\
(0.021)\end{array}$ \\
\hline Parental age square & & & & $\begin{array}{l}-0.000 \\
(0.000)\end{array}$ & $\begin{array}{c}-0.000 \\
(0.000)\end{array}$ & $\begin{array}{c}-0.000 \\
(0.000)\end{array}$ \\
\hline $\begin{array}{l}\text { Parental age } \\
\times \text { Reform }\end{array}$ & & & & $\begin{array}{l}-0.028 \\
(0.035)\end{array}$ & $\begin{array}{l}-0.026 \\
(0.035)\end{array}$ & $\begin{array}{l}-0.024 \\
(0.035)\end{array}$ \\
\hline
\end{tabular}




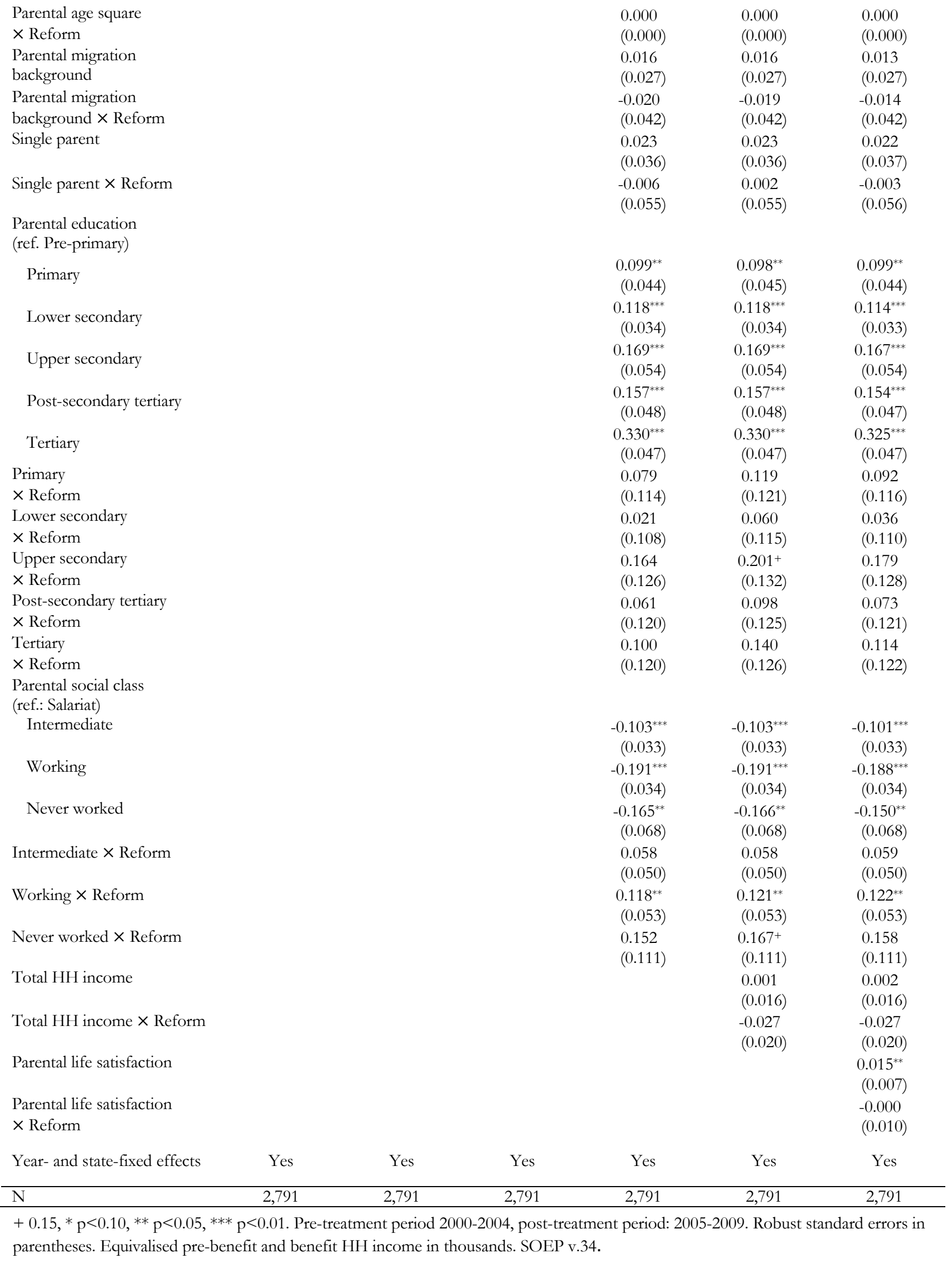


Table A2. Academic track attendance by parental benefit receipt, before and after reform (Logit)

\begin{tabular}{|c|c|c|c|c|c|c|}
\hline & $\begin{array}{c}(1) \\
\text { Main effects }\end{array}$ & $\begin{array}{c}(2) \\
\text { Baseline }\end{array}$ & $\begin{array}{c}(3) \\
+ \text { Pre-benefit } \\
\text { HH income }\end{array}$ & $\begin{array}{c}\text { (4) } \\
+ \text { Socio- } \\
\text { demographics }\end{array}$ & $\begin{array}{c}\text { (5) } \\
+ \text { Total } \\
\text { HH income }\end{array}$ & $\begin{array}{c}\text { (6) } \\
+ \text { Parental life } \\
\text { satisfaction }\end{array}$ \\
\hline \multicolumn{7}{|l|}{$\begin{array}{l}\text { Parental benefit receipt } \\
\text { (ref.: No benefits) }\end{array}$} \\
\hline Unemployment benefits & $\begin{array}{r}-0.806^{* * *} \\
(0.226)\end{array}$ & $\begin{array}{r}-0.641^{* *} \\
(0.281)\end{array}$ & $\begin{array}{l}-0.305 \\
(0.276)\end{array}$ & $\begin{array}{l}-0.024 \\
(0.276)\end{array}$ & $\begin{array}{l}-0.025 \\
(0.276)\end{array}$ & $\begin{array}{l}0.008 \\
(0.280)\end{array}$ \\
\hline Unemployment assistance & $\begin{array}{r}-1.414^{* * *} \\
(0.266)\end{array}$ & $\begin{array}{r}-1.214^{* * *} \\
(0.299)\end{array}$ & $\begin{array}{r}-0.467^{+} \\
(0.315)\end{array}$ & $\begin{array}{l}-0.464 \\
(0.349)\end{array}$ & $\begin{array}{l}-0.264 \\
(0.496)\end{array}$ & $\begin{array}{l}-0.208 \\
(0.493)\end{array}$ \\
\hline Social assistance & $\begin{array}{r}-1.964^{* * *} \\
(0.316)\end{array}$ & $\begin{array}{r}-2.808^{* * *} \\
(0.746)\end{array}$ & $\begin{array}{r}-1.865^{* *} \\
(0.756)\end{array}$ & $\begin{array}{r}-1.787^{* *} \\
(0.828)\end{array}$ & $\begin{array}{l}-1.631^{*} \\
(0.943)\end{array}$ & $\begin{array}{l}-1.639^{*} \\
(0.951)\end{array}$ \\
\hline Reform & $\begin{array}{l}0.188^{* *} \\
(0.083)\end{array}$ & $\begin{array}{r}1.571^{* *} \\
(0.663)\end{array}$ & $\begin{array}{l}1.587^{* *} \\
(0.699)\end{array}$ & $\begin{array}{l}3.385 \\
(4.870)\end{array}$ & $\begin{array}{l}3.056 \\
(4.702)\end{array}$ & $\begin{array}{l}2.929 \\
(4.646)\end{array}$ \\
\hline $\begin{array}{l}\text { Unemployment benefits } \\
\times \text { Reform }\end{array}$ & & $\begin{array}{l}-0.495 \\
(0.468)\end{array}$ & $\begin{array}{l}-0.529 \\
(0.463)\end{array}$ & $\begin{array}{l}-0.663 \\
(0.502)\end{array}$ & $\begin{array}{l}-0.455 \\
(0.507)\end{array}$ & $\begin{array}{l}-0.440 \\
(0.504)\end{array}$ \\
\hline Unemployment assistance & & $-1.219^{+}$ & -1.008 & -1.104 & -0.475 & -0.440 \\
\hline$\times$ Reform & & $(0.783)$ & $(0.800)$ & $(0.825)$ & $(0.957)$ & $(0.951)$ \\
\hline $\begin{array}{l}\text { Social assistance } \\
\times \text { Reform }\end{array}$ & & $\begin{array}{l}1.154 \\
(0.835)\end{array}$ & $\begin{array}{l}1.211 \\
(0.859)\end{array}$ & $\begin{array}{l}1.106 \\
(0.931)\end{array}$ & $\begin{array}{l}1.918^{*} \\
(1.159)\end{array}$ & $\begin{array}{l}2.028^{*} \\
(1.177)\end{array}$ \\
\hline \multicolumn{7}{|l|}{ Age at transition (ref.: 9) } \\
\hline 10 & $\begin{array}{r}0.723^{* * *} \\
(0.203)\end{array}$ & $\begin{array}{r}0.929^{* * *} \\
(0.323)\end{array}$ & $\begin{array}{l}0.868^{* *} \\
(0.347)\end{array}$ & $\begin{array}{l}0.841^{* *} \\
(0.351)\end{array}$ & $\begin{array}{c}0.836^{* *} \\
(0.351)\end{array}$ & $\begin{array}{c}0.846^{* *} \\
(0.356)\end{array}$ \\
\hline 11 & $\begin{array}{c}0.526^{* *} \\
(0.205)\end{array}$ & $\begin{array}{r}0.931^{* * *} \\
(0.323)\end{array}$ & $\begin{array}{r}0.995^{* * *} \\
(0.346)\end{array}$ & $\begin{array}{r}1.020^{* * *} \\
(0.351)\end{array}$ & $\begin{array}{r}1.019^{* * *} \\
(0.351)\end{array}$ & $\begin{array}{r}1.024^{* * *} \\
(0.356)\end{array}$ \\
\hline 12 & $\begin{array}{l}0.033 \\
(0.268)\end{array}$ & $\begin{array}{c}0.572^{+} \\
(0.382)\end{array}$ & $\begin{array}{l}0.670^{+} \\
(0.410)\end{array}$ & $\begin{array}{l}0.744^{*} \\
(0.421)\end{array}$ & $\begin{array}{l}0.737^{*} \\
(0.422)\end{array}$ & $\begin{array}{l}0.759^{*} \\
(0.428)\end{array}$ \\
\hline 13 & $\begin{array}{l}0.265 \\
(0.617)\end{array}$ & $\begin{array}{l}0.334 \\
(0.677)\end{array}$ & $\begin{array}{l}0.634 \\
(0.702)\end{array}$ & $\begin{array}{l}1.012 \\
(0.786)\end{array}$ & $\begin{array}{l}1.003 \\
(0.787)\end{array}$ & $\begin{array}{l}0.993 \\
(0.775)\end{array}$ \\
\hline 14 & $\begin{array}{c}-11.465^{* * *} \\
(0.848)\end{array}$ & $\begin{array}{c}-12.518^{* * *} \\
(1.139)\end{array}$ & $\begin{array}{c}-12.067^{* * *} \\
(1.174)\end{array}$ & $\begin{array}{c}-14.754^{* * *} \\
(1.241)\end{array}$ & $\begin{array}{c}-13.762^{* * *} \\
(1.241)\end{array}$ & $\begin{array}{c}-14.008^{* * *} \\
(1.240)\end{array}$ \\
\hline $10 \times$ Reform & & $\begin{array}{c}-0.360 \\
(0.427)\end{array}$ & $\begin{array}{l}-0.365 \\
(0.455)\end{array}$ & $\begin{array}{l}-0.374 \\
(0.465)\end{array}$ & $\begin{array}{c}-0.344 \\
(0.464)\end{array}$ & $\begin{array}{l}-0.369 \\
(0.468)\end{array}$ \\
\hline $11 \times$ Reform & & $\begin{array}{c}-0.833^{*} \\
(0.431)\end{array}$ & $\begin{array}{c}-0.866^{*} \\
(0.456)\end{array}$ & $\begin{array}{c}-0.861^{*} \\
(0.470)\end{array}$ & $\begin{array}{c}-0.837^{*} \\
(0.468)\end{array}$ & $\begin{array}{c}-0.854^{*} \\
(0.473)\end{array}$ \\
\hline $12 \times$ Reform & & $\begin{array}{r}-1.345^{* *} \\
(0.581)\end{array}$ & $\begin{array}{r}-1.388^{* *} \\
(0.612)\end{array}$ & $\begin{array}{r}-1.543^{* *} \\
(0.666)\end{array}$ & $\begin{array}{r}-1.504^{* *} \\
(0.669)\end{array}$ & $\begin{array}{r}-1.537^{* *} \\
(0.671)\end{array}$ \\
\hline $13 \times$ Reform & & $\begin{array}{c}16.057^{* * *} \\
(1.499)\end{array}$ & $\begin{array}{c}15.666^{* * *} \\
(1.508)\end{array}$ & $\begin{array}{c}18.351^{* * *} \\
(1.584)\end{array}$ & $\begin{array}{r}16.735^{* * *} \\
(1.588)\end{array}$ & $\begin{array}{r}17.006^{* * *} \\
(1.578)\end{array}$ \\
\hline $14 \times$ Reform & & $\begin{array}{l}0.173 \\
(1.646)\end{array}$ & $\begin{array}{l}-0.065 \\
(1.676)\end{array}$ & $\begin{array}{l}-0.037 \\
(1.797)\end{array}$ & $\begin{array}{l}0.192 \\
(1.797)\end{array}$ & $\begin{array}{l}-0.127 \\
(1.799)\end{array}$ \\
\hline Female & $\begin{array}{l}0.037 \\
(0.082)\end{array}$ & $\begin{array}{l}0.036 \\
(0.110)\end{array}$ & $\begin{array}{l}0.051 \\
(0.115)\end{array}$ & $\begin{array}{l}0.155 \\
(0.122)\end{array}$ & $\begin{array}{l}0.151 \\
(0.122)\end{array}$ & $\begin{array}{l}0.149 \\
(0.123)\end{array}$ \\
\hline Female $\times$ Reform & & $\begin{array}{l}-0.026 \\
(0.168)\end{array}$ & $\begin{array}{l}0.030 \\
(0.175)\end{array}$ & $\begin{array}{l}-0.055 \\
(0.186)\end{array}$ & $\begin{array}{c}-0.033 \\
(0.186)\end{array}$ & $\begin{array}{l}-0.018 \\
(0.187)\end{array}$ \\
\hline Pre-benefit income & & & $\begin{array}{r}0.074^{* * *} \\
(0.009)\end{array}$ & $\begin{array}{r}0.027^{* * *} \\
(0.008)\end{array}$ & $\begin{array}{l}0.106 \\
(0.164)\end{array}$ & $\begin{array}{l}0.094 \\
(0.164)\end{array}$ \\
\hline Pre-benefit income & & & -0.001 & 0.012 & 0.215 & 0.230 \\
\hline$\times$ Reform & & & $(0.015)$ & $(0.014)$ & $(0.220)$ & $(0.222)$ \\
\hline HH members age $0-14$ & & & & $\begin{array}{l}0.103 \\
(0.073)\end{array}$ & $\begin{array}{l}0.102 \\
(0.073)\end{array}$ & $\begin{array}{l}0.092 \\
(0.073)\end{array}$ \\
\hline HH members age $0-14$ & & & & -0.000 & 0.009 & 0.010 \\
\hline$\times$ Reform & & & & $(0.110)$ & (0.111) & (0.111) \\
\hline Parental age & & & & $\begin{array}{l}0.167 \\
(0.140)\end{array}$ & $\begin{array}{l}0.167 \\
(0.139)\end{array}$ & $\begin{array}{l}0.171 \\
(0.141)\end{array}$ \\
\hline Parental age square & & & & $\begin{array}{l}-0.002 \\
(0.002)\end{array}$ & $\begin{array}{l}-0.002 \\
(0.002)\end{array}$ & $\begin{array}{l}-0.002 \\
(0.002)\end{array}$ \\
\hline $\begin{array}{l}\text { Parental age } \\
\times \text { Reform }\end{array}$ & & & & $\begin{array}{c}-0.144 \\
(0.216)\end{array}$ & $\begin{array}{c}-0.147 \\
(0.216)\end{array}$ & $\begin{array}{c}-0.137 \\
(0.216)\end{array}$ \\
\hline
\end{tabular}


Parental age square

$\times$ Reform

Parental migration

$(0.003)$

0.133

(0.164)

background

Parental migration

background $\times$ Reform

$-0.133$

Single parent

(0.246)

0.083

(0.241)

Single parent $\times$ Reform

0.008

(0.352)

Parental education

(ref. Pre-primary)

Primary

Lower secondary

$14.358^{* * *}$

(0.802)

$14.720^{* * *}$

(0.498)

Upper secondary

$15.012^{\text {*** }}$

(0.747)

Post-secondary tertiary

$14.948^{* * *}$

(0.626)

Tertiary

Primary

$\times$ Reform

Lower secondary

$\times$ Reform

Upper secondary

$\times$ Reform

Post-secondary tertiary

$\times$ Reform

Tertiary

$\times$ Reform

Parental social class

(ref.: Salariat)

Intermediate

Working

Never worked

$15.671^{* * *}$

(0.428)

0.655

(.)

0.083

(0.664)

0.777

0.281

(2.053)

0.489

(1.810)

$$
0.002
$$

0.002

(0.003)

(0.003)

0.132

0.118

$-0.123$

(0.165)

(0.245)

$-0.094$

(0.245)

0.087

0.081

(0.241)

(0.244)

0.057

0.033

(0.354)

(0.359)

$-0.443^{* * *}$

(0.157)

$-1.074^{* * *}$

$13.373^{* * *}$

(0.506)

$13.611^{* * *}$

$13.730^{* * *}$

(0.351)

(0.397)

$13.930^{\text {*** }}$

$14.026^{* * *}$

$14.236^{* * *}$

(0.489)

(0.288)

$13.957^{* * *}$

(0.431)

$14.160^{* * *}$

(0.227)

$14.686^{* * *}$

$14.886^{* * *}$

(0.394)

(0.102)

1.033

$0.860^{*}$

(1.134)

(0.444)

0.461

$0.312^{*}$

(0.554)

(0.169)

1.140

$1.009^{+}$

(1.106)

(0.682)

0.652

(1.209)

0.498

(.)

0.708

(1.098)

(0.541)

(0.195)

$-0.738$

(0.567)

0.241

(0.244)

$0.685^{* *}$

(0.301)

0.796

(0.780)

$-0.442^{* * *}$

$-0.429^{* * *}$

(0.157)

(0.158)

$-1.072^{* * *}$

$-1.061^{* * *}$

(0.196)

$-0.626$

$-0.711$

(0.567)

(0.571)

0.239

0.237

(0.244)

Working $\times$ Reform

Never worked $\times$ Reform

$0.691^{* *}$

$0.701^{* *}$

(0.301)

(0.302)

0.916

0.836

$0.794) \quad(0.804)$
$-0.079)$

Total HH income

$-0.079$

$-0.069$

(0.164) (0.164)

$-0.204 \quad-0.217$

Total HH income $\times$ Reform

(0.220)

$(0.222)$

$0.086^{* *}$

$(0.039)$

0.000

(0.059)

Parental life satisfaction

$\times$ Reform

Year- and state-fixed effects

$\mathrm{N} 2,791$

Yes

Yes

Yes

Yes

$\begin{array}{cc}\text { Yes } & \text { Yes } \\ 2,791 & 2,791\end{array}$

$+0.15,{ }^{*} \mathrm{p}<0.10,{ }^{* *} \mathrm{p}<0.05,{ }^{* * *} \mathrm{p}<0.01$. Pre-treatment period 2000-2004, post-treatment period: 2005-2009. Robust standard errors in parentheses. Equivalised pre-benefit and benefit $\mathrm{HH}$ income in thousands. SOEP v.34. 
Table A3. Academic track attendance by parental benefit receipt, parallel trends before reform (OLS)

\begin{tabular}{|c|c|c|}
\hline & $\begin{array}{c}\text { (1) } \\
\text { Main effects }\end{array}$ & $\begin{array}{c}(2) \\
\text { Year interactions }\end{array}$ \\
\hline \multicolumn{3}{|l|}{$\begin{array}{l}\text { Parental benefit receipt } \\
\text { (ref.: No benefits) }\end{array}$} \\
\hline Unemployment benefits & $-0.131^{* *}(0.052)$ & $-0.085(0.112)$ \\
\hline Unemployment assistance & $-0.223^{* * *}(0.043)$ & $-0.228^{* * *}(0.086)$ \\
\hline Social assistance & $-0.331^{* * *}(0.034)$ & $-0.314^{* * *}(0.037)$ \\
\hline \multicolumn{3}{|l|}{ Year (ref.: 2000) } \\
\hline 2001 & $0.026(0.035)$ & $0.034(0.038)$ \\
\hline 2002 & $0.044(0.035)$ & $0.052(0.039)$ \\
\hline 2003 & $0.102^{* * *}(0.037)$ & $0.102^{* *}(0.040)$ \\
\hline 2004 & $0.093^{* *}(0.036)$ & $0.090^{* *}(0.040)$ \\
\hline Unemployment benefits $\times 2001$ & & $-0.094(0.155)$ \\
\hline Unemployment benefits $\times 2002$ & & $-0.138(0.140)$ \\
\hline Unemployment benefits $\times 2003$ & & $-0.015(0.182)$ \\
\hline Unemployment benefits $\times 2004$ & & $0.035(0.168)$ \\
\hline Unemployment assistance $\times 2001$ & & $-0.082(0.103)$ \\
\hline Unemployment assistance $\times 2002$ & & $0.028(0.129)$ \\
\hline Unemployment assistance $\times 2003$ & & $0.020(0.143)$ \\
\hline Unemployment assistance $\times 2004$ & & $0.071(0.136)$ \\
\hline Social assistance $\times 2001$ & & $0.051(0.115)$ \\
\hline Social assistance $\times 2002$ & & $-0.031(0.055)$ \\
\hline Social assistance $\times 2003$ & & $-0.002(0.143)$ \\
\hline Social assistance $\times 2004$ & & $-0.095^{+}(0.061)$ \\
\hline \multicolumn{3}{|l|}{$\begin{array}{l}\text { Federal state of secondary school } \\
\text { (ref.: Schleswig-Holstein) }\end{array}$} \\
\hline Hamburg & $0.050(0.132)$ & $0.051(0.132)$ \\
\hline Lower Saxony & $-0.083(0.078)$ & $-0.081(0.078)$ \\
\hline Bremen & $0.105(0.204)$ & $0.122(0.206)$ \\
\hline North Rhine-Westphalia & $0.034(0.075)$ & $0.036(0.074)$ \\
\hline Hesse & $0.030(0.082)$ & $0.030(0.082)$ \\
\hline Rhineland-Palatinate & $-0.065(0.082)$ & $-0.065(0.082)$ \\
\hline Baden-Württemberg & $-0.060(0.076)$ & $-0.057(0.076)$ \\
\hline Bavaria & $-0.052(0.075)$ & $-0.053(0.075)$ \\
\hline Saarland & $-0.132(0.109)$ & $-0.126(0.110)$ \\
\hline Berlin & $0.083(0.102)$ & $0.083(0.103)$ \\
\hline Brandenburg & $0.062(0.096)$ & $0.062(0.096)$ \\
\hline Mecklenburg-Vorpommern & $0.061(0.120)$ & $0.071(0.120)$ \\
\hline Saxony & $0.029(0.093)$ & $0.024(0.094)$ \\
\hline Saxony-Anhalt & $0.096(0.099)$ & $0.098(0.100)$ \\
\hline Thuringia & $0.109(0.104)$ & $0.111(0.104)$ \\
\hline \multicolumn{3}{|l|}{ Age at transition (ref.: 9) } \\
\hline 10 & $0.161^{* * *}(0.047)$ & $0.159^{* * *}(0.047)$ \\
\hline 11 & $0.160^{* * *}(0.046)$ & $0.158^{* * *}(0.047)$ \\
\hline 12 & $0.091+(0.059)$ & $0.090^{+}(0.060)$ \\
\hline 13 & $0.041(0.128)$ & $0.038(0.129)$ \\
\hline 14 & $-0.234^{*}(0.120)$ & $-0.233^{*}(0.120)$ \\
\hline Female & $0.007(0.023)$ & $0.007(0.024)$ \\
\hline Constant & $0.177^{* *}(0.084)$ & $0.175^{* *}(0.084)$ \\
\hline $\mathrm{N}$ & 1,599 & 1,599 \\
\hline
\end{tabular}

$+0.15, * \mathrm{p}<0.10,{ }^{* *} \mathrm{p}<0.05,{ }^{* * *} \mathrm{p}<0.01$. Robust standard errors in parentheses. 
Table A4. Academic track attendance by parental benefit receipt, placebo analysis (OLS)

\begin{tabular}{|c|c|c|c|c|}
\hline & $\begin{array}{c}\text { (1) } \\
\text { Main effects }\end{array}$ & $\begin{array}{c}(2) \\
\text { Baseline } \\
\end{array}$ & $\begin{array}{c}\text { (3) } \\
\text { Main effects } \\
\end{array}$ & $\begin{array}{c}(4) \\
\text { Baseline }\end{array}$ \\
\hline \multicolumn{5}{|l|}{$\begin{array}{l}\text { Parental benefit receipt } \\
\text { (ref.: No benefits) }\end{array}$} \\
\hline Unemployment benefits & $\begin{array}{r}-0.160^{* * * *} \\
(0.038)\end{array}$ & $\begin{array}{r}-0.159^{* * *} \\
(0.052)\end{array}$ & $\begin{array}{r}-0.252^{* * *} \\
(0.041)\end{array}$ & $\begin{array}{r}-0.271^{* * *} \\
(0.060)\end{array}$ \\
\hline Unemployment assistance & $\begin{array}{r}-0.189^{* * *} \\
(0.035)\end{array}$ & $\begin{array}{r}-0.150^{* * *} \\
(0.050)\end{array}$ & $\begin{array}{r}-0.305^{* * *} \\
(0.056)\end{array}$ & $\begin{array}{r}-0.351^{* * *} \\
(0.055)\end{array}$ \\
\hline Social assistance & $\begin{array}{r}-0.329^{* * *} \\
(0.034)\end{array}$ & $\begin{array}{r}-0.305^{* * *} \\
(0.038)\end{array}$ & $\begin{array}{r}-0.295^{* * *} \\
(0.021)\end{array}$ & $\begin{array}{r}-0.296^{* * *} \\
(0.049)\end{array}$ \\
\hline Reform & $\begin{array}{r}0.069^{* * *} \\
(0.020)\end{array}$ & $\begin{array}{c}0.272^{* *} \\
(0.135)\end{array}$ & $\begin{array}{l}0.001 \\
(0.019)\end{array}$ & $\begin{array}{r}-0.206^{+} \\
(0.131)\end{array}$ \\
\hline $\begin{array}{l}\text { Unemployment benefits } \\
\times \text { Reform }\end{array}$ & & $\begin{array}{l}0.008 \\
(0.078)\end{array}$ & & $\begin{array}{l}0.047 \\
(0.083)\end{array}$ \\
\hline Unemployment assistance & & -0.082 & & 0.078 \\
\hline$\times$ Reform & & $(0.070)$ & & $(0.129)$ \\
\hline Social assistance & & -0.021 & & 0.004 \\
\hline$\times$ Reform & & $(0.057)$ & & $(0.055)$ \\
\hline \multicolumn{5}{|l|}{ Age at transition (ref.: 9) } \\
\hline 10 & $\begin{array}{r}0.158^{* * *} \\
(0.038)\end{array}$ & $\begin{array}{r}0.146^{* * *} \\
(0.054)\end{array}$ & $\begin{array}{l}0.079^{* *} \\
(0.035)\end{array}$ & $\begin{array}{l}0.125^{*} \\
(0.064)\end{array}$ \\
\hline 11 & $\begin{array}{r}0.147^{* * *} \\
(0.038)\end{array}$ & $\begin{array}{r}0.165^{* * *} \\
(0.053)\end{array}$ & $\begin{array}{l}-0.023 \\
(0.036)\end{array}$ & $\begin{array}{l}0.029 \\
(0.065)\end{array}$ \\
\hline 12 & $\begin{array}{l}0.069^{+} \\
(0.047)\end{array}$ & $\begin{array}{l}0.117^{*} \\
(0.070)\end{array}$ & $\begin{array}{r}-0.182^{* * *} \\
(0.043)\end{array}$ & $\begin{array}{l}-0.102 \\
(0.084)\end{array}$ \\
\hline 13 & $\begin{array}{l}0.132 \\
(0.114)\end{array}$ & $\begin{array}{r}0.443^{* * *} \\
(0.168)\end{array}$ & $\begin{array}{r}-0.173^{*} \\
(0.102)\end{array}$ & $\begin{array}{r}0.928^{* * *} \\
(0.133)\end{array}$ \\
\hline 14 & $\begin{array}{r}-0.241^{* *} \\
(0.110)\end{array}$ & $\begin{array}{l}-0.238 \\
(0.181)\end{array}$ & $\begin{array}{r}-0.414^{* * *} \\
(0.089)\end{array}$ & $\begin{array}{l}-0.127 \\
(0.126)\end{array}$ \\
\hline $10 \times$ Reform & & $\begin{array}{l}0.048 \\
(0.077)\end{array}$ & & $\begin{array}{l}-0.071 \\
(0.077)\end{array}$ \\
\hline $11 \times$ Reform & & $\begin{array}{l}-0.011 \\
(0.076)\end{array}$ & & $\begin{array}{l}-0.080 \\
(0.078)\end{array}$ \\
\hline $12 \times$ Reform & & $\begin{array}{l}-0.043 \\
(0.096)\end{array}$ & & $\begin{array}{l}-0.109 \\
(0.098)\end{array}$ \\
\hline $13 \times$ Reform & & $\begin{array}{r}-0.472^{* *} \\
(0.213)\end{array}$ & & $\begin{array}{r}-1.192^{* * *} \\
(0.168)\end{array}$ \\
\hline $14 \times$ Reform & & $\begin{array}{c}0.000 \\
(.)\end{array}$ & & $\begin{array}{r}-0.365^{* *} \\
(0.164)\end{array}$ \\
\hline Female & $\begin{array}{l}0.007 \\
(0.019)\end{array}$ & $\begin{array}{l}0.017 \\
(0.027)\end{array}$ & $\begin{array}{l}0.012 \\
(0.017)\end{array}$ & $\begin{array}{l}0.001 \\
(0.030)\end{array}$ \\
\hline Female $\times$ Reform & & $\begin{array}{c}-0.022 \\
(0.038)\end{array}$ & & $\begin{array}{l}0.015 \\
(0.036)\end{array}$ \\
\hline Year- and state-fixed effects & Yes & Yes & Yes & Yes \\
\hline $\mathrm{N}$ & 2,311 & 2,311 & 3,047 & 3,047 \\
\hline
\end{tabular}

$+0.15,{ }^{*} \mathrm{p}<0.10,{ }^{* *} \mathrm{p}<0.05,{ }^{* * *} \mathrm{p}<0.01$. Columns (1)-(2): Pre-treatment period 1997-2000, post-treatment period: 2001-2004. Columns (3)-(4): Pre-treatment period 2005-2008, post-treatment period: 2009-2012. Robust standard errors in parentheses. SOEP v.34. 
Figure A1. Quasi-experimental study design

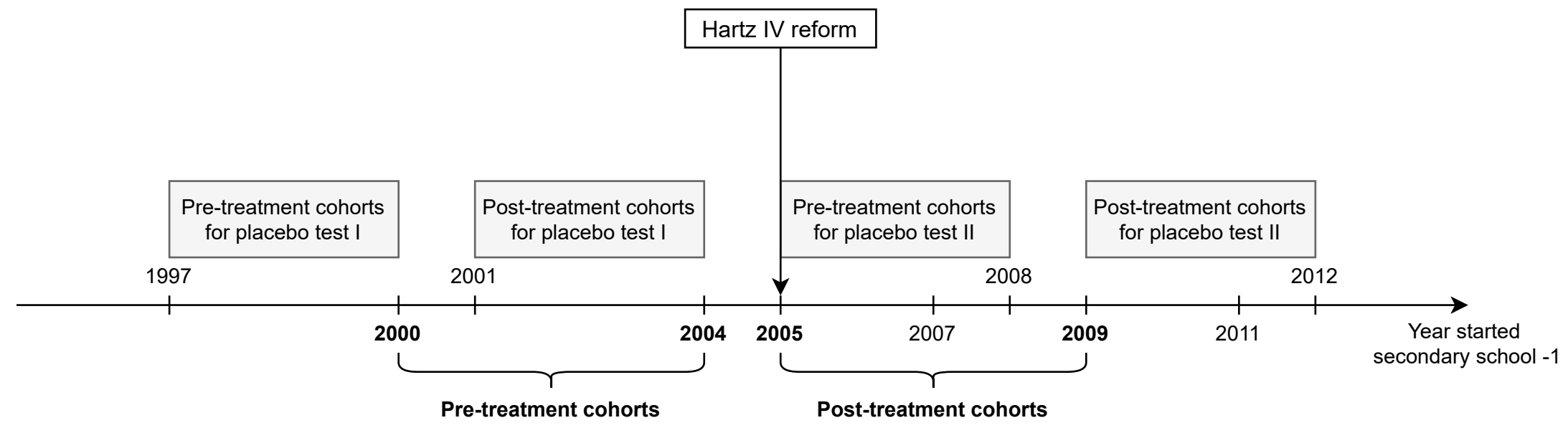

